\title{
Trade credit, trade income elasticity and the international transmission of shocks
}

\author{
Anna Watson ${ }^{1}$ (D) \\ Received: 7 October 2020 / Revised: 30 May 2021 / Accepted: 4 June 2021 / \\ Published online: 27 July 2021 \\ (C) The Author(s) 2021
}

\begin{abstract}
The paper examines the impact of trade credit on cyclical fluctuations in international trade. It provides new empirical evidence based on firm-level UK and Irish data showing that exporters use trade credit more actively and intensively than nonexporters. The study introduces inter-firm lending into an open economy general equilibrium model with heterogeneous firms and endogenous entry into the exports market. It demonstrates that trade credit amplifies the impact of macroeconomic shocks on international trade both along the intensive and extensive margins and that it significantly contributes to the high trade income elasticity observed in the data.
\end{abstract}

Keywords Trade credit · International trade $\cdot$ Business cycle fluctuations $\cdot$ Trade income elasticity

JEL Classification F41 $\cdot$ E32 $\cdot$ E51

\section{Introduction}

One of the prevalent features of international business cycle fluctuations which is difficult to reconcile with standard open economy macroeconomic models is the high volatility of imports and exports relative to output and strong procyclicality

\footnotetext{
I am very grateful to Sean Holly, Giancarlo Corsetti, Philip Lane, Sergejs Saksonovs, Paul Youdell, Oliver de Groot as well as the participants of the 2018 Royal Economic Society Annual Conference, the 2018 European Trade Study Group Annual Conference, the EEA-ESEM 2019 and the 32nd EBES Conference for their helpful comments and suggestions. I also wish to thank the editor and two anonymous referees for their invaluable comments and advice.
}

Anna Watson

ac531@cam.ac.uk

1 Faculty of Economics and Fitzwilliam College, University of Cambridge, Storey's Way,

Cambridge CB3 0DG, UK 
of international trade. The average elasticity of world trade to world income was estimated to be equal to 1.7 during the second half of the last century (Irwin, 2002) and 3.7 in the 2000s (Freund, 2009). ${ }^{1}$ In contrast, a canonical international business cycle model implies trade income elasticity equal to one. While recent research has demonstrated that the high sensitivity of international trade to changes in output can to some extent be explained by the composition of international trade, vertical trade integration and inventory adjustment (Alessandria et al., 2010; Bems et al., 2010; Bussière et al., 2013; Eaton et al., 2016; Engel \& Wang, 2011; Levchenko et al., 2010), the impact of financial factors on cyclical trade fluctuations is not well understood. This paper investigates whether and to what extent trade credit representing inter-firm lending contributes to the high volatility of international trade flows and the procyclicality of trade openness, measured by the trade to output ratio.

The key contribution of this paper lies in its analysis of the impact of trade credit on cyclical fluctuations in international trade and the international transmission of shocks. The paper first provides new empirical evidence on the differences in the intensity of trade credit use by exporting and non-exporting firms based on financial data of 60,000 firms in the UK and Ireland. It shows that the percentage of firms supplying and receiving trade credit is higher among exporters than non-exporters and that firms engaged in international trade extend significantly more credit to their customers as a fraction of their revenues than firms serving only the domestic market. Secondly, the study introduces inter-firm lending and counterparty risk into an open-economy general equilibrium model with heterogeneous firms and the extensive margin of trade. It then examines how trade credit alters the transmission of shocks in the economy and the dynamics of international trade.

Trade credit, which allows customers to delay payment until some time after delivery and is mostly associated with the purchase of intermediate goods, is one of the most important sources of short-term financing for firms (Demirguc-Kunt \& Maksimovic, 2001; Petersen \& Rajan, 1997; Rajan \& Zingales, 1995; Kohler et al., 2000). Corporate surveys indicate that the majority of firms make the majority of their sales on credit (Wilson \& Summers, 1997). Raddatz (2010) reports that in 60 percent of countries covered by Worldscope trade credit constitutes a more important source of short-term financing for firms than bank credit.

Trade credit plays a particularly important role in facilitating international trade. It is estimated that between 80 to 90 percent of international transactions rely on some trade finance facilities (Auboin, 2009). According to the IMF/BAFT-IFSA Trade Finance Surveys, over 60 percent of these transactions are supported by trade credit (Asmundson et al., 2011). ${ }^{2}$ While most empirical studies on trade credit do not distinguish between its use in domestic and international trade, Eck et al. (2012) demonstrate, based on German survey data, that companies that export their goods

\footnotetext{
1 High income elasticity of trade flows is also documented by OECD (2010) and Aiello et al. (2015).

2 The most common form of trade finance, used in about 40 percent of transactions, is open account financing, in which the exporter grants credit to the importer directly and bears the non-payment risk. A further 20 per cent of transactions are financed through cash-in-advance in which the exporter receives trade credit from the importer.
} 
are significantly more likely to extend and receive trade credit than firms selling their goods only on the domestic market and they also have relatively larger average shares of transactions for which trade credit is given and received. There are a number of factors which may contribute to the relatively more intensive use of trade credit in international transactions. Firstly, due to the fact that international trade involves longer shipment times and additional time for the completion of crossborder administrative procedures, ${ }^{3}$ it is associated with longer time lags between production and the receipt of sales revenues, including trade credit repayments. This leads to greater working capital requirements and it also increases the value of accounts receivable in proportion to annual sales revenues, which is the standard measure of the intensity of trade credit provision. ${ }^{4}$ Secondly, exporters, which are on average larger and more productive than non-exporting firms ${ }^{5}$ tend to have better access to external finance and may be in a better position to supply trade credit to their customers. ${ }^{6}$ Furthermore, Eck et al. (2012) show within a theoretical model, for which they find empirical support, that the widespread use of trade credit in international trade may be due to the inherently greater degree of uncertainty in international than in domestic transactions. Trade credit can reduce this uncertainty and alleviate the resulting financial constraints by serving as a quality signalling device.

Trade credit exposes its supplier to a counterparty risk which has been shown to be substantial. Using French firm-level data, Boissay and Gropp (2007) show that defaults on trade credit are common—on average 19 percent of firms default at least once per quarter. The defaults faced by firms correspond on average to about 2 percent of their receivables. The average share of quarterly defaults in current liquid assets is as high as 44 percent-they can therefore constitute a major liquidity shock. Jacobson and Schedvin (2015) demonstrate using Swedish data that trade credit suppliers incur considerable trade credit losses due to trade debtor failures and that their bankruptcy risks increase with the size of the losses incurred. The authors find that 8.3 percent of firms face at least one trade debtor failure in a year and that firm failures impose larger credit losses on the corporate sector than on the banking sector. Bradley and Rubach (2002) and Bradley and Cowdery (2004) find that nonpayment of trade credit by customers is one of the most important causes of bankruptcy among US firms. The high risk associated with trade credit is reflected in the relatively high cost of this type of financing. The discount rates typically offered for early payment, which can serve as a proxy for trade credit price, are equivalent to annual interest rates of over 40 percent (Boissay, 2006; Petersen \& Rajan, 1997).

\footnotetext{
3 See Hummels and Schaur (2013) and Djankov et al. (2010) for empirical evidence.

4 Due to the way in which the ratio of accounts receivable to sales revenues is calculated, it reflects both the fraction of goods which are sold and purchased on credit terms and the average time period within which the credit is repaid.

5 Bernard and Jensen $(1995,1997,1999,2004)$ provide extensive empirical evidence of this phenomenon while Melitz (2003) explains it within a theoretical framework.

${ }^{6}$ Manova (2013) and Chaney (2016) show theoretically that financially constrained firms are less likely to export their goods and their results were confirmed empirically by Buch et al. (2010), Bellone et al. (2010), Minetti and Chun Zhu (2011) and Muuls (2015) for German, French, Italian and Belgian firms, respectively.
} 
Cuñat (2007) shows theoretically and empirically that the high interest rates on trade credit arise from the existence of a default premium and a premium for insurance against potential liquidity shocks, which the supplier provides for the customer. As the non-payment risk depends on macroeconomic conditions and changes over the business cycle, inter-firm lending can be expected to play a role in the propagation of shocks in the economy.

In the model developed in this paper, macroeconomic shocks affect the default rate among firms and the fraction of trade credit which is not repaid. Changes in the riskiness of inter-firm loans lead to changes in their cost, which in turn alters firms' marginal costs and prices. Due to the differences in the intensity of trade credit use in domestic and international transactions, macroeconomic shocks and the accompanying changes in the counterparty risk associated with inter-firm lending affect the domestic and foreign market price of traded varieties differently, which leads to changes in the relative price of domestic and imported goods. Macroeconomic shocks as well as the resulting changes in international relative prices affect the profitability of exports and induce changes in the fraction of varieties which are traded internationally. This causes further adjustment in the relative price of and the demand for domestic and imported goods and, in consequence, also in the volume of international trade.

This study demonstrates that due to differences in the riskiness of international and domestic transactions, cyclical changes in the cost of trade credit amplify the impact of macroeconomic shocks on trade both along the intensive and extensive margins. The model generates trade income elasticities considerably larger than one and shows that inter-firm lending significantly contributes to the high volatility and strong procyclicality of international trade flows observed in the data.

The remainder of the paper is organized as follows. Section 2 discusses related literature. In Sect. 3 new empirical evidence on the use of trade credit by exporters and non-exporters in Ireland and in the UK is presented. Section 4 outlines the model developed to account for the impact of inter-firm lending on cyclical fluctuations in international trade. Section 5 describes the calibration of the model parameters. In Sect. 6 the quantitative effects of trade credit on cyclical trade fluctuations and the international transmission of shocks are discussed. The last section concludes.

\section{Related literature}

This paper contributes to the literature that attempts to explain the stylized facts of international business cycles, in particular those related to trade. A number of studies point to the role of the composition of international trade in accounting for its cyclical fluctuations. Engel and Wang (2011) document the high volatility and procyclicality of both imports and exports and show that they can be attributed to a large extent to trade in durable goods. Boileau (1999) and Erceg et al. (2008) demonstrate that trade in capital goods significantly contributes to the volatility of international trade, net exports and the terms of trade. The importance of compositional effects in accounting for the dynamics of international trade has also been confirmed by Levchenko et al. (2010), Bussière et al. (2013) and Eaton et al. (2016). Bems 
et al. (2010) emphasize the significance of vertical linkages and vertical specialization in understanding international trade flows. Inventory adjustment has been identified as another factor responsible for the high volatility of international trade (Alessandria et al., 2010). Ghironi and Melitz (2005) show that accounting for firms' heterogeneity and endogenous entry into the exports market helps explain a number of features of international business cycle fluctuations including the Harrod-Balassa-Samuelson effect. Raffo (2008) highlights home production as an important factor determining the behavior of net exports and the terms of trade. Jiang (2016) explores the effects of demand shocks within the international real business cycle framework and finds that they are essential in accounting for the procyclicality and high volatility of imports, exports and trade openness. In contrast to previous studies, this paper investigates the role of inter-firm lending in explaining the dynamics of international trade. While there is a growing literature on financial frictions in open economies and their impact on international business cycles (e.g. Faia, 2007; Iacoviello \& Minetti, 2006; Kollmann et al., 2011; Perri \& Quadrini, 2018; Yao, 2019), existing research in this area does not generally focus on explaining the stylized facts associated with international trade flows.

The paper also relates to the literature on inter-firm lending. While the motivation behind the widespread use of trade credit has been studied extensively both from a theoretical and an empirical perspective, ${ }^{7}$ the macroeconomic implications of this type of financing are not well understood. Until recently, research in this area focused predominantly on a closed economy and the use of trade credit in domestic transactions. Kiyotaki and Moore (1997) showed within a partial equilibrium framework that trade credit can amplify the effects of shocks on the level of economic activity. In the presence of trade credit supply chains, a temporary shock to the liquidity of some firms may trigger a sequence of bankruptcies and a severe decline in output, as firms facing a default by their customers may be forced to default on their own suppliers, propagating the shock through the economy. This theory was subsequently extended to a general equilibrium framework and tested empirically (Boissay, 2006; Boissay \& Gropp, 2007; Cardoso-Lecourtois, 2004; Jacobson \& Schedvin, 2015; Raddatz, 2010). Conversely, a number of studies investigated whether and to what extent trade credit may help to mitigate the impact of shocks to the economy by providing an alternative to bank loans as a source of external finance for firms in times of tight monetary policy and financial distress (Atanasova \& Wilson, 2003; Calomiris et al., 1995; Choi \& Kim, 2005; Garcia-Appendini \& Montoriol-Garriga, 2013; Guariglia \& Mateut, 2006; Huang et al., 2011; Kohler et al., 2000; Love et al., 2007; Mateut et al., 2006). Both propositions found some empirical support. Using a model of inventory investment with capital market imperfections, Yang (2011) demonstrated that, depending on monetary policy conditions, trade credit and bank credit can be either substitutes or complements. Khan et al. (2020) showed that trade credit can alleviate the adverse impact of uncertainty on firms by weakening the negative relationship between uncertainty and leverage. Alexandre and Lima (2020), who analyzed the macroeconomic effects of trade credit in a closed economy using

\footnotetext{
7 For an overview of the literature see Petersen and Rajan (1997) and Klapper et al. (2012).
} 
an agent-based model, found that the availability of trade credit may facilitate financial robustness but at the cost of lowering the average level of output in the economy.

While the great trade collapse of 2008-2009 triggered by the global financial crisis generated considerable interest in the role of trade credit in an international context, studies on this topic focus almost exclusively on the microfoundations of inter-firm lending and the choice of trade finance instruments by firms (Ahn, 2011; Antràs \& Foley, 2015; Schmidt-Eisenlohr, 2013) rather than on their consequences for international business cycles. Furthermore, they are conducted within a partial equilibrium framework. Patel (2016) provides a notable exception by examining the interaction between trade finance and monetary policy in a two-country New Keynesian DSGE model and showing that it plays a significant role in the international propagation of shocks. This paper, by contrast, investigates the impact of inter-firm lending on cyclical fluctuations of international trade along the intensive and extensive margins. ${ }^{8}$

\section{Trade credit use-empirical evidence}

There are two main measures of the intensity of trade credit use: the ratio of accounts receivable to sales revenues, which represents trade credit that firms provide to their customers, and the ratio of accounts payable to the cost of goods sold, which corresponds to trade credit that firms obtain from their suppliers. ${ }^{9}$ Trade credit constitutes a substantial component of corporate assets and liabilities. Dass et al. (2015) show using Compustat data that in the period from 1997 to 2008 the average value of accounts receivable to sales in the US was 17.8 percent, while the average ratio of accounts payable to sales was 12.9 percent. Raddatz (2010) reports that in a sample of 43 countries the ratio of accounts payable to the cost of goods sold ranges from 7 to 33 percent and its mean and median values are equal to 15 and 14 percent, respectively.

While trade credit is prevalent both in domestic and international transactions, it is particularly widely used by exporting firms. Eck et al. (2012) examined the differences in the patterns of inter-firm lending between internationally active and nonactive firms based on German data from the 2004 Business Environment and Enterprise Performance Surveys (BEEPS). The authors demonstrate that exporters use trade credit more actively and more intensively than non-exporting firms. 94 percent of exporters supply trade credit to their customers, as compared to 80 percent of non-exporters. The fractions of firms obtaining trade credit from their trading partners are equal to 96 percent for exporters and 92 percent for non-exporters. The average share of transactions for which trade credit is provided is also significantly

\footnotetext{
${ }^{8}$ Changes in trade along the intensive margin refer to changes in the volume of already traded varieties, whereas changes in trade along the extensive margin correspond to changes in the number of varieties traded.

9 For a given firm and a given year these ratios are equal to the average value of accounts receivable/ accounts payable at the end of the current and the previous year divided by the total value of sales revenues/cost of goods sold in the current year.
} 
higher for internationally active firms and is equal to 64 percent for exporters and 49 percent for non-exporters. The corresponding shares of transactions for which trade credit is received are equal to 75 percent among exporters and 63 percent among non-exporting firms.

This study provides new evidence on the discrepancies in the pattern of trade credit use between exporters and non-exporters. Analysis of financial data from the 60,000 largest British and Irish companies reveals that trade credit is a major source of short-term financing for firms and that it is considerably more widely used by companies engaged in international trade than by firms serving only the domestic market. The firms covered by the analysis jointly represent over 99 percent of the total revenue and over 99.9 of the total employment in the corporate sector in Ireland and in the UK.

An overwhelming majority of British and Irish firms gives and receives trade credit. Between 2003 and 2014 on average 80 percent of the 60,000 largest British and Irish companies recorded positive values of 'trade debtors', which corresponds to trade credit granted, and 83 percent of these firms had positive values of 'trade creditors', which represents trade credit received. Inter-firm lending was even more widespread in the manufacturing sector, in which on average 84 percent of firms provided trade credit to their customers and 83 percent of firms obtained trade credit from their suppliers. The average ratio of trade debtors to sales revenues in the period covered by the analysis was equal to 13 percent among manufacturing firms and 12 percent overall.

The fraction of UK and Irish firms providing trade credit to their customers is considerably higher among exporters than non-exporters. The pattern of a more intensive use of trade credit by internationally active firms is very pronounced both in manufacturing and in the entire population of firms. It is also independent of the firms' scale of operation. Table 1 shows a range of measures of the intensity of trade credit use by UK and Irish manufacturing firms in the period 2003-2014, while Table 2 provides similar statistics for firms from all sectors of the economy. The three measures of the intensity of trade credit provision presented are the mean and median values of the ratio of trade debtors to turnover (TN and TD, respectively), which represents trade credit granted as a fraction of sales revenues, and the percentage of firms for which the value of trade debtors is positive (TF) and which are therefore trade credit providers. ${ }^{10}$

In the manufacturing sector the measures of trade credit use are calculated for two different subgroups of firms - the largest 1000 and 10,000 companies in terms of their revenues. ${ }^{11}$ Among the top 1000 manufacturing firms, 97 percent of exporters and 93 percent of non-exporters extended trade credit to their customers. The average ratio of trade credit granted to turnover was equal to 12.6 percent among

\footnotetext{
10 Among the 15,000 largest manufacturing firms about 66 percent reported their national and overseas turnover separately, which made it possible to determine their export status and include them in the sample for which the measures of trade credit use were calculated. The fraction of firms for which export status could be determined was equal to 53 percent among the 60,000 largest UK and Irish firms.

11 The revenues of the firms included in these different subgroups represent on average 82 and over 99 percent of total revenues generated in the manufacturing industry, respectively.
} 


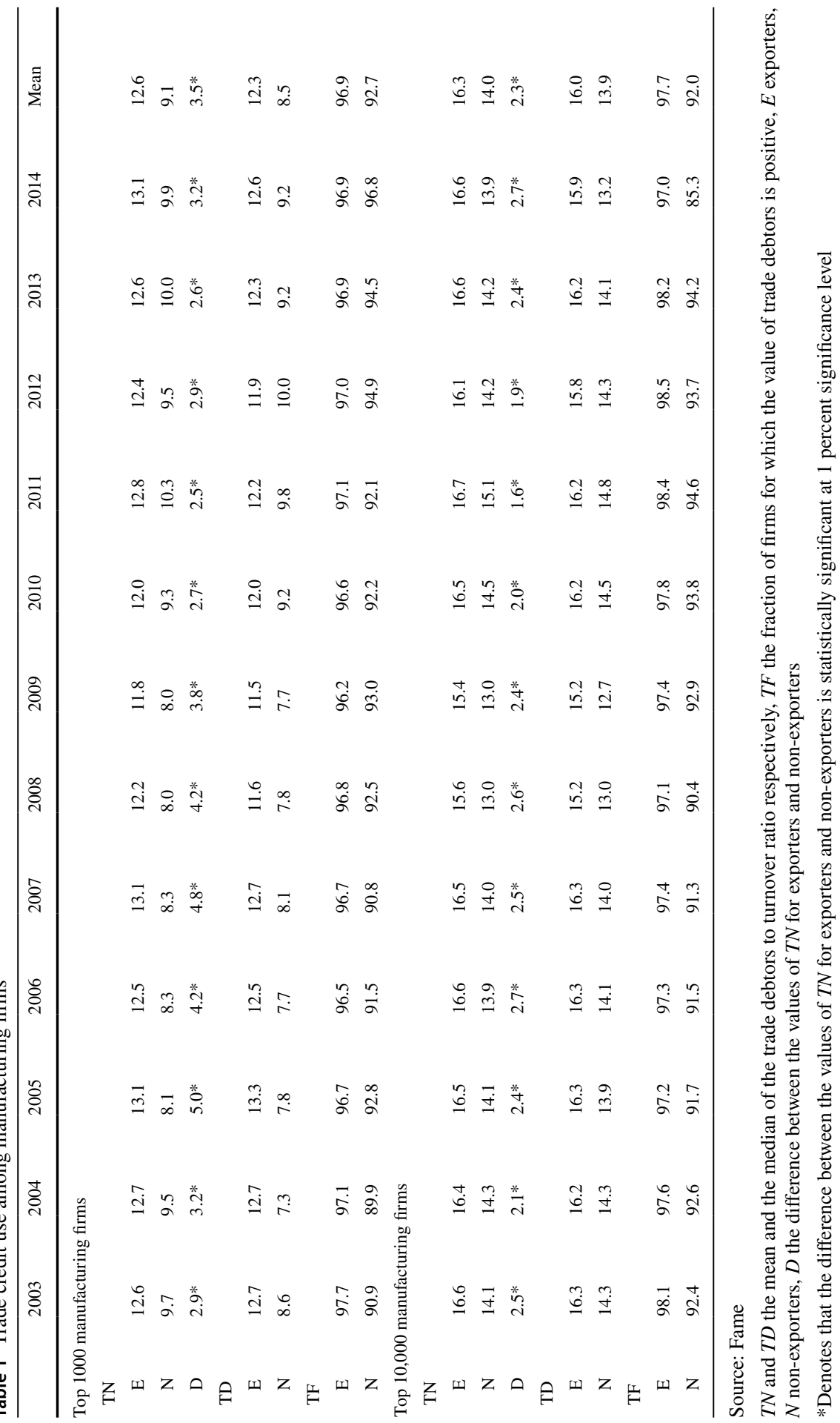




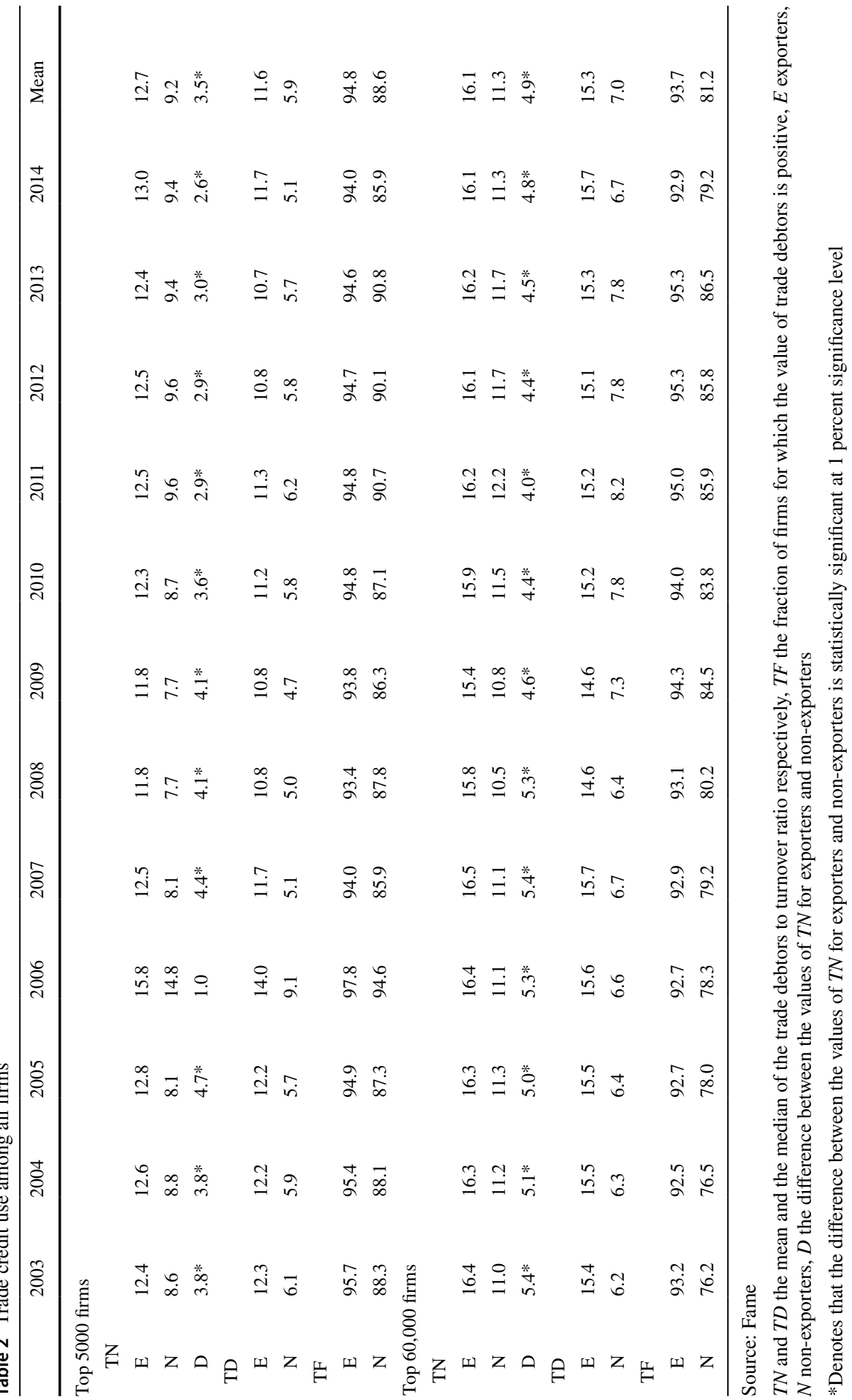


internationally active firms and 9.1 percent among firms selling their goods only on the domestic market. If we assume that trade credit is usually granted for about two months, in line with the empirical evidence provided by Klapper et al. (2012), then this would imply similar estimates of the intensity of trade credit use by exporters and non-exporters to the ones obtained by Eck et al. (2012) for German firms based on survey data. For all the different sample sizes and all the different years covered by the analysis the mean ratio of trade debtors to revenues was higher for exporters than for non-exporters-with the average difference ranging from 2.3 to 3.5 percentage points, depending on the number of firms included in the analysis. For all sample sizes and all years the differences in the means are statistically significant at the 1 percent significance level. ${ }^{12}$ Similarly, for all sample sizes and all years considered the fraction of exporters granting trade credit is higher than the fraction of nonexporters acting as trade credit providers. Over the time period analyzed, the average difference between these fractions lies between 4.2 percentage points for the largest 1000 firms and 5.7 percentage points for the largest 10,000 firms.

The relatively more widespread use of inter-firm lending by exporters is not limited to manufacturing firms and can be observed among all firms in the economy. Among the top 60,000 British and Irish firms, representing over 99 percent of corporate sector revenues, on average 94 percent of exporters acted as trade credit providers, as compared to 81 percent of non-exporters. The average ratio of trade debtors to turnover in the period analyzed was equal to 16.1 percent for exporters and 11.3 percent for non-exporting firms. For all sample sizes and for all years covered by the analysis apart from one the differences in the ratios of trade debtors to turnover for exporters and non-exporters were positive, substantial and statistically significant at the significance level of 1 percent. ${ }^{13}$ Furthermore, for all sample sizes and all years the percentage of firms extending trade credit is relatively higher among firms engaged in international trade and the differences in the ratios of trade credit providers among exporters and non-exporters range from an average of 6.2 percentage points for the largest 5000 firms to an average of 12.5 percentage points for the largest 60,000 firms.

The ratio of accounts receivable to sales revenues reflects the extent to which the trade credit supplier is exposed to non-payment risk on the part of its customers. The more extensive use of trade credit by internationally active firms leaves them more exposed to the counterparty risk associated with such credit and more vulnerable to changes in macroeconomic conditions which affect the risk of non-payment. The next section develops a model which introduces trade credit and counterparty risk into an open-economy general equilibrium framework with heterogeneous firms and which is then used to analyze the effects of inter-firm lending on the international transmission of shocks.

\footnotetext{
12 Tables 1 and 2 show that the ratio of trade debtors to turnover is remarkably stable over time, although it somewhat declined during the global financial crisis of 2008-2009. This indicates that the value of trade credit granted is closely related to sales revenues and is therefore strongly procyclical.

13 The revenues of the companies included in the subsamples of the top 5000 and 60,000 firms examined represent on average 87 and over 99 percent of total revenues generated by UK and Irish firms, respectively.
} 


\section{Model}

The world economy consists of two symmetric countries: Home and Foreign. Each country is populated by utility-maximizing households and profit-maximizing, monopolistically competitive firms. There are two types of firms: intermediate goods producers and final goods producers. Intermediate goods producers employ domestic labor in order to produce intermediate inputs and sell them to the producers of final consumption goods. They decide whether to sell their goods only in the domestic market or whether to export them as well. Final goods producers combine intermediate inputs produced both in the domestic and in the foreign economy in order to produce differentiated final consumption goods, which are then sold to domestic households. When selling their goods, the intermediate goods suppliers provide trade credit to final goods producers and are thereby exposed to credit risk. In each period an endogenously determined fraction of trade credit granted is not repaid as a result of defaults in the sector producing final consumption goods. Business cycles are driven by aggregate productivity shocks and preference shocks leading to changes in aggregate demand. It is assumed that prices are flexible and that households have access to a complete set of state-contingent assets traded internationally.

All firms in the economy are subject to idiosyncratic productivity shocks. In the sector of intermediate goods, firm heterogeneity with regard to productivity leads to time-varying entry into the exports market and generates fluctuations in international trade along the extensive margin. Idiosyncratic productivity shocks in the sector of final consumption goods result in time-varying defaults in this sector which affect the cost of trade credit and the relative prices of domestic and foreign goods and contribute to changes in trade along the intensive margin. As the number of traded varieties determines the share of each variety in the consumption basket and as changes in the relative demand for domestic and foreign goods affect the profitability of exports, these two margins of trade interact with each other. As in the seminal paper by Melitz (2003), firm heterogeneity is integrated into the model in such a way that all the information on the distribution of productivity levels across firms which is relevant for aggregate outcomes is completely summarized by productivity averages for different categories of firms.

\subsection{Households}

In each country there is a continuum of identical, infinitely-lived households. A representative household supplies labor to the producers of intermediate and final consumption goods in the domestic economy and consumes a basket of final consumption goods. Its period utility function is additively separable in consumption, $C_{t}$, and labor, $L_{t}$, and is given by: 


$$
E_{t} \sum_{k=0}^{\infty} \beta^{k}\left[\frac{C_{t+k}^{1-\sigma}}{1-\sigma} e^{u_{t}}-\frac{L_{t+k}^{1+\varphi}}{1+\varphi}\right]
$$

where $\beta \in(0,1)$ is the intertemporal discount factor, $\sigma>0$ is the inverse of the intertemporal elasticity of substitution in consumption, $\varphi \geq 0$ is the inverse of the Frisch elasticity of labor supply, $e^{u_{t}}$ represents a shock to the marginal utility of consumption such that $u_{t}=\gamma_{u} u_{t-1}+\xi_{t}^{u}, \gamma_{u} \in(0 ; 1)$ and $\xi_{t}^{u} \sim N\left(0, \sigma_{u}^{2}\right)$.

Households choose their consumption and labor supply in order to maximize their expected discounted lifetime utility subject to a sequence of budget constraints:

$$
P_{t} C_{t}+E_{t}\left[O_{t, t+1} D_{t+1}\right]=W_{t} L_{t}+D_{t}+\Pi_{t}
$$

where $P_{t}$ is the aggregate price level in the Home economy at time $t, W_{t}$ denotes nominal wage and $\Pi_{t}$ is a lump sum component of households' income including dividends from the ownership of firms. $O_{t, t+1}$ is the stochastic discount factor for one-period ahead nominal payoffs, $D_{t+1}$ is the nominal payoff in period $t+1$ of the portfolio held at the end of period $t$. Households have unrestricted access to a complete set of internationally traded state-contingent claims.

The solution to the household decision problem gives the following intratemporal labor supply equation:

$$
\frac{W_{t}}{P_{t}}=C_{t}^{\sigma} L_{t}^{\varphi} e^{-u_{t}}
$$

which equalizes real wage with the marginal rate of substitution between consumption and leisure.

The optimal consumption choice in the Home economy satisfies the following intertemporal Euler equation:

$$
C_{t}^{-\sigma} e^{u_{t}}=\beta E_{t}\left[C_{t+1}^{-\sigma} e^{u_{t+1}} \frac{1}{O_{t, t+1}} \frac{P_{t}}{P_{t+1}}\right]
$$

while in the Foreign economy the consumption Euler equation is given by: ${ }^{14}$

$$
C_{t}^{*-\sigma} e^{u_{t}^{*}}=\beta E_{t}\left[C_{t+1}^{*-\sigma} e^{u_{t+1}^{*}} \frac{1}{O_{t, t+1}} \frac{S_{t} P_{t}^{*}}{S_{t+1} P_{t+1}^{*}}\right]
$$

where $S_{t}$ is the nominal exchange rate, expressed as the price of one unit of the foreign currency in terms of the domestic currency.

Assuming that the Home and Foreign economies are initially perfectly symmetric, the well-known risk-sharing condition holds:

$$
\left(\frac{C_{t}}{C_{t}^{*}}\right)^{\sigma} e^{\left(u_{t}^{*}-u_{t}\right)}=\frac{S_{t} P_{t}^{*}}{P_{t}}
$$

14 Throughout the paper, Foreign variables are denoted by an asterisk. 
according to which the ratio of marginal utilities of consumption in the Home and Foreign economy is equal to the ratio of relative prices of consumption in these economies.

Each household consumes all varieties of the final consumption goods which are produced in the domestic economy and are indexed by $j$. The consumption aggregator, $C_{t}$, is defined as:

$$
C_{t}=\left[\int_{0}^{1} C_{j, t}^{\frac{\theta_{B}-1}{\theta_{B}}} d j\right]^{\frac{\theta_{B}}{\theta_{B}-1}}
$$

where $\theta_{B}>0$ is the elasticity of substitution between final consumption goods. The utility-based consumption price index, $P_{t}$, is therefore given by:

$$
P_{t}=\left[\int_{0}^{1} P_{j, t}^{1-\theta_{B}} d j\right]^{\frac{1}{1-\theta_{B}}}
$$

Given households' preferences specified above, the demand for variety $j$ of the final consumption good, denoted by $C_{j, t}$, is positively related to the aggregate demand in the Home economy, $C_{t}$, and negatively related to the price of this variety, $P_{j, t}$, relative to the aggregate price index,$P_{t}$, and can be written as:

$$
C_{j, t}=\left(\frac{P_{j, t}}{P_{t}}\right)^{-\theta_{B}} C_{t}
$$

\subsection{Firms}

\subsubsection{Intermediate goods producers}

Each economy is populated by a continuum of monopolistically competitive intermediate goods producers, indexed by $i$ on the unit interval. They employ domestic labor in order to produce differentiated intermediate goods using a production technology given by:

$$
V_{i, t}=Z_{t} A_{i, t} L_{i, t}
$$

where $V_{i, t}$ is the output produced by firm $i$ at time $t$ and $L_{i, t}$ is the labor input used in the production of that good. Firms are heterogeneous with regard to their productivity. Their productivity level in a given period is determined by two components: $Z_{t}$, 
which is common to all intermediate goods producers and is subject to aggregate shocks such that $\ln Z_{t}=z_{t}$ and $z_{t}=\gamma_{z} z_{t-1}+\xi_{t}^{z}$ where $\gamma_{z} \in(0 ; 1)$ and $\xi_{t}^{z} \sim N\left(0, \sigma_{z}^{2}\right)$ as well as $A_{i, t}$, which is firm-specific. The idiosyncratic productivity draws $A_{i, t}$ are independent across firms and over time and they come from a distribution which is time-invariant.

All the varieties of intermediate goods produced in the domestic economy are sold to the producers of final consumption goods in the domestic economy. Some of them are in addition sold abroad and the decision to export is endogenous. When selling their goods, intermediate goods producers receive a fraction of their revenues at the beginning of the period, before delivery, while the remaining part of the revenues is paid at the end of the period, after the goods are delivered. The fraction of revenues which is paid in advance of delivery and is therefore safe from counterparty risk is equal to $\left(1-d_{H}\right)$ for the domestic buyers and $\left(1-d_{F}\right)$ for the foreign buyers. The parameters $d_{H}$ and $d_{F}$ can be interpreted as a measure of the trade credit provided by the domestic producers of intermediate goods to the domestic and foreign producers of final consumption goods, which is subject to non-repayment risk. It is assumed that $d_{F}>d_{H}$, which reflects the relatively more intensive usage of trade credit by exporting firms resulting, among other factors, from the longer time lags between the dispatch and delivery of goods in international trade. ${ }^{15}$

Due to the fact that in each period a fraction of final goods producers incurs losses and defaults on their debt, at the end of the period intermediate goods suppliers recover only a fraction of the trade credit extended. This fraction is equal to $\left(1-\rho_{t}\right)$ for trade credit granted to domestic final goods producers and $\left(1-\rho_{t}^{*}\right)$ for trade credit granted to foreign final goods producers, where $\rho_{t}$ and $\rho_{t}^{*}$ are the Home and Foreign trade credit default rates respectively - the fractions of the total value of trade credit received by Home and Foreign final goods producers which are not repaid. The default risk, and as a result also the trade credit default rates, are endogenous and change over time with changes in macroeconomic conditions driven by aggregate shocks. As trade credit suppliers are assumed to hold sufficiently large and diversified portfolios to ensure perfect risk pooling, they behave as if they were risk neutral.

4.2.1.1 Domestic market All intermediate goods producers sell their goods in the domestic economy. The supply of the variety $i$ produced and sold in the Home economy is denoted by $V_{H, i, t}$ and is equal to:

$$
V_{H, i, t}=Z_{t} A_{i, t} L_{H, i, t}
$$

Firm $i$ chooses the amount of labor $L_{H, i, t}$ used in the production of intermediate input $i$ for the Home market and the price of the input on this market $Q_{H, i, t}$ in order to maximize its profits subject to the demand function and the production technology.

\footnotetext{
15 While in this paper the difference in the trade credit provision by exporters and non-exporters is exogenously imposed, it would arise endogenously in a richer model incorporating multi-period loans and a time-to-ship friction in international trade.
} 
The profit of intermediate goods producer $i$ obtained from sales of goods in the Home economy is given by:

$$
\pi_{H, i, t}=\left[\left(1-d_{H}\right)+d_{H}\left(1-\rho_{t}\right)\right] Q_{H, i, t} X_{H, i, t}-X_{H, i, t} \frac{W_{t}}{A_{i, t} Z_{t}}
$$

where $X_{H, i, t}$ is the total demand for the intermediate good $i$ by Home producers of final consumption goods and it is given by:

$$
X_{H, i, t}=\int_{0}^{1} X_{H, i, j, t} d j
$$

$X_{H, i, j, t}$ is the demand for the intermediate variety $i$ by final goods producer $j$, which depends on the relative price of this variety on the Home market, $\frac{Q_{H, i, t}}{Q_{t}}$, the total number of varieties of intermediate goods available for sale in the Home economy, equal to $2-N_{t}^{*}$, as well as the aggregate demand for intermediate goods by the Home producer $j$, denoted by $X_{j, t}{ }^{16}$

The optimal allocation of expenditures by producer $j$ between the different varieties of the intermediate input available in the domestic market implies:

$$
X_{H, i, j, t}=\left(\frac{1}{2-N_{t}^{*}}\right)\left(\frac{Q_{H, i, t}}{Q_{t}}\right)^{-\theta_{A}} X_{j, t}
$$

where $\theta_{A}$ is the elasticity of substitution between intermediate inputs. $Q_{t}$ is the aggregate price index for the intermediate goods in the Home economy, which is given by:

$$
Q_{t}=\left[\left(\frac{1}{2-N^{*}}\right) Q_{H, t}^{1-\theta_{A}}+\left(\frac{1-N^{*}}{2-N^{*}}\right) Q_{F, t}^{1-\theta_{A}}\right]^{\frac{1}{1-\theta_{A}}}
$$

where $Q_{H, t}$ and $Q_{F, t}$ are the aggregate price indices for the Home and Foreign intermediate goods, respectively, and are equal to:

$$
Q_{H, t}=\left(\int_{0}^{1} Q_{H, i, t}^{1-\theta_{A}}\right)^{\frac{1}{1-\theta_{A}}}
$$

and

$$
Q_{F, t}=\left(\int_{N^{*}}^{1} Q_{F, i, t}^{1-\theta_{A}}\right)^{\frac{1}{1-\theta_{A}}}
$$

\footnotetext{
16 The number of varieties of intermediate goods available for sale in the Home economy is equal to $2-N_{t}^{*}$, as 2 is the mass of intermediate goods producers in the whole world and $N_{t}^{*}$ is the share of intermediate goods producers in the Foreign economy who do not export their goods.
} 
The total domestic demand for the variety produced by firm $i$ is therefore equal to:

$$
X_{H, i, t}=\left(\frac{1}{2-N_{t}^{*}}\right)\left(\frac{Q_{H, i, t}}{Q_{t}}\right)^{-\theta_{A}} X_{t}
$$

where:

$$
X_{t}=\int_{0}^{1} X_{j, t} d j
$$

In equilibrium the total demand for the intermediate good $i$ in the Home market, $X_{H, i, t}$, needs to be equal to the supply of this good on this market, $V_{H, i, t}: X_{H, i, t}=V_{H, i, t}$

At the beginning of each period the intermediate goods supplier sets the price for its good and is then prepared to sell it to any final goods producer at this price. When setting the price, the intermediate goods producers know the realization of all the aggregate shocks as well as their idiosyncratic productivity level in that period. They also know the properties of the distributions of firm-specific shocks in their sector and in the sector producing final consumption goods, which are the same at home and abroad and which do not change over time. The profit-maximizing price for the Home market is equal to a constant mark-up over marginal cost:

$$
Q_{H, i, t}=\frac{\theta_{A}}{\theta_{A}-1} \frac{W_{t}}{A_{i, t} Z_{t}} g_{H, t}
$$

where $g_{H, t}$ is given by:

$$
g_{H, t}=\frac{1}{\left(1-d_{H}\right)+d_{H}\left(1-\rho_{t}\right)}
$$

and can be interpreted as the cost of the trade credit suppliers' insurance against the domestic buyers' default. Equation (20) shows that endogenous changes in the trade credit default rate among final goods producers, $\rho_{t}$, affect the marginal cost and prices of the producers of intermediate goods and, as a result, also the demand for these goods.

4.2.1.2 Export decision In each period the intermediate goods producers decide whether to export their goods in addition to selling them in the domestic economy. If a Home intermediate goods producer $i$ decides to export its good, then the supply of this variety on the foreign market is equal to $V_{F, i, t}$ :

$$
V_{F, i, t}=Z_{t} A_{i, t} L_{F, i, t}
$$

and it is a function of the firm's level of productivity and the domestic labor employed in the production of this good for exports, denoted by $L_{F, i, t}$.

In order to sell their goods abroad, the intermediate goods producers need to pay a fixed cost of entering the exports market, equal to $F_{A}$ effective units of domestic 
labor. When exporting, they also incur an additional variable iceberg trade cost equal to a constant fraction $\tau$ of the value of the goods exported. Firms can decide whether to enter the exports market in period $t$ after observing all the aggregate shocks in that period and also their idiosyncratic productivity levels, $A_{i, t}$. When making their export decisions, the intermediate goods producers also know the properties of the distributions of firm-specific productivity in the sector producing final consumption goods at home and abroad, $B_{j, t}$ and $B_{j, t}^{*}$, which are time-invariant. Firms only choose to export their goods if the additional profits from the sale of goods abroad are greater than or equal to the fixed export market entry cost:

$$
\left[\left(1-d_{F}\right)+d_{F}\left(1-\rho_{t}^{*}\right)\right] S_{t} Q_{F, i, t}^{*} X_{F, i, t}^{*}-(1+\tau) X_{F, i, t}^{*} \frac{W_{t}}{A_{i, t} Z_{t}}-F_{A} \frac{W_{t}}{Z_{t}} \geq 0
$$

where $Q_{F, i, t}^{*}$ is the foreign-currency price of the variety produced by firm $i$ and sold in the foreign market and $X_{F, i, t}^{*}$ is the demand for this variety in the Foreign economy.

If a firm decides to export its variety, its price for the foreign market (in foreign currency) is set optimally and is equal to a constant mark-up over marginal cost:

$$
Q_{F, i, t}^{*}=\frac{\theta_{A}}{\theta_{A}-1} \frac{W_{t}}{A_{i, t} Z_{t}}(1+\tau) g_{F, t}^{*} \frac{1}{S_{t}}
$$

where $g_{F, t}^{*}$ is given by:

$$
g_{F, t}^{*}=\frac{1}{\left(1-d_{F}\right)+d_{F}\left(1-\rho_{t}^{*}\right)}
$$

Comparison of (24) with (20) reveals that due to the presence of iceberg trade costs and the fact that international transactions are associated with greater counterparty risk than domestic transactions, the domestic currency price of variety $i$ on the Foreign market is higher than the price of this variety in the Home economy and the law of one price does not hold. This, combined with the fact that only a fraction of domestically produced varieties is exported, generates home bias in consumption and leads to deviations from purchasing power parity (PPP).

After substituting (24) into (23), the export market entry condition can be expressed as:

$$
\frac{1}{\theta_{A}} S_{t} Q_{F, i, t}^{*} X_{F, i, t}^{*}-F_{A} \frac{W_{t}}{Z_{t}} \geq 0
$$

where 


$$
X_{F, i, t}^{*}=\int_{0}^{1} X_{F, i, j, t}^{*} d j
$$

and $X_{F, i, j, t}^{*}$ is the demand for the intermediate variety $i$ by final goods producer $j$, which depends on the relative price of this variety on the foreign market, $\frac{Q_{F, i, t}^{*}}{Q_{t}^{*}}$, the total number of varieties of intermediate goods available for sale in the foreign economy, equal to $2-N_{t}$, as well as the aggregate demand for intermediate goods by the Foreign producer $j$, denoted by $X_{j, t}^{*}$ and given by:

$$
X_{F, i, j, t}^{*}=\left(\frac{1}{2-N_{t}}\right)\left(\frac{Q_{F, i, t}^{*}}{Q_{t}^{*}}\right)^{-\theta_{A}} X_{j, t}^{*}
$$

The total foreign demand for the variety produced by firm $i$ is therefore equal to:

$$
X_{F, i, t}^{*}=\left(\frac{1}{2-N_{t}}\right)\left(\frac{Q_{F, i, t}^{*}}{Q_{t}^{*}}\right)^{-\theta_{A}} X_{t}^{*}
$$

where

$$
X_{t}^{*}=\int_{0}^{1} X_{j, t}^{*} d j
$$

and in equilibrium it needs to be equal to the supply of this good on the foreign market: $X_{F, i, t}^{*}=V_{F, i, t}$.

In consequence, the threshold level of productivity above which firms export their goods, denoted by $\bar{A}_{t}$, is determined by the condition:

$$
\frac{1}{\theta_{A}}\left(\frac{1}{2-N_{t}}\right)\left(\frac{\theta_{A}}{\theta_{A}-1} \frac{g_{F, t}^{*}}{\bar{A}_{t}}\right)^{1-\theta_{A}}\left(\frac{W_{t}}{Z_{t}}\right)^{-\theta_{A}} X_{t}^{*}\left(S_{t} Q_{t}^{*}\right)^{\theta_{A}}=F_{A}
$$

4.2.1.3 Productivity distribution As in Ghironi and Melitz (2005) and in line with empirical evidence on firms' size distribution, it is assumed that the firm-specific level of productivity, $A_{t}$, in the intermediate goods sector is Pareto distributed. Its cumulative distribution function is given by $F(A)=1-\left(\frac{A_{\min }}{A}\right)^{k_{A}}$, where $A_{\min }$ is the lower bound and $k_{A}$ is a shape parameter, such that $k_{A}>\theta_{A}-1$, which determines the dispersion of productivity draws across firms. As $k_{A}$ increases, dispersion decreases and the firm productivity levels are increasingly concentrated towards their lower bound, $A_{\text {min. }}{ }^{17}$

\footnotetext{
${ }^{17}$ Following Ghironi and Melitz (2005), the assumption that firms' productivity is Pareto distributed has been widely adopted in the literature on heterogeneous firms and trade (for an overview see Redding, 2011).
} 
Assuming that firms' productivity is Pareto distributed, the probability that at time $t$ it is not profitable for a firm to export its goods is equal to:

$$
N_{t}=F\left(\bar{A}_{t}\right)=1-\left(\frac{A_{\min }}{\bar{A}_{t}}\right)^{k_{A}}
$$

whereas the probability of exporting is equal to:

$$
1-N_{t}=1-F\left(\bar{A}_{t}\right)=\left(\frac{A_{\min }}{\bar{A}_{t}}\right)^{k_{A}}
$$

Hence, $N_{t}$ and $\left(1-N_{t}\right)$ denote the fractions of non-exporters and exporters among intermediate goods producers in the Home economy.

Denoting $v_{A}=\left[\frac{k_{A}}{k_{A}-\left(\theta_{A}-1\right)}\right]^{\frac{1}{\theta_{A}-1}}$, the average productivity among all intermediate goods producers, $A_{A}$, can be defined as:

$$
A_{A}=\left[\int_{A_{\min }}^{\infty} A_{t}^{\theta_{A}-1} d F(A)\right]^{\frac{1}{\theta_{A}-1}}=v_{A} A_{\min }
$$

The productivity averages among exporters and non-exporters in the Home economy can be expressed as functions of the threshold level of productivity, $\bar{A}_{t}$, and the probability of non-exporting, $N_{t}$. The average productivity among non-exporting intermediate goods producers, $A_{N, t}$, is given by:

$$
\begin{aligned}
A_{N, t} & =\left[\frac{1}{F\left(\bar{A}_{t}\right)} \int_{A_{\min }}^{\bar{A}_{t}} A_{t}^{\theta_{A}-1} d F(A)\right]^{\frac{1}{\theta_{A}-1}} \\
& =v_{A}\left[\frac{1}{N_{t}} A_{\min }^{\theta_{A}-1}-\frac{\left(1-N_{t}\right)}{N_{t}}\left(\bar{A}_{t}\right)^{\theta_{A}-1}\right]^{\frac{1}{\theta_{A}-1}}
\end{aligned}
$$

The average productivity among exporting intermediate goods producers, $A_{E, t}$, is equal to:

$$
A_{E, t}=\left[\frac{1}{1-F\left(\bar{A}_{t}\right)} \int_{\bar{A}_{t}}^{\infty} A_{t}^{\theta_{A}-1} d F(A)\right]^{\frac{1}{\theta_{A}-1}}=v_{A} \bar{A}_{t}
$$




\subsubsection{Final goods producers}

In each economy there is a continuum of final goods producers, indexed by $j$ on the unit interval. As in the case of intermediate goods producers, final goods producers differ with regard to their productivity. At the beginning of period $t$, before learning their productivity levels in that period, domestic retailers need to incur a fixed cost of production, which is equal to the cost of $F_{B}$ effective units of domestic labor. After the aggregate and firm-specific shocks are revealed, domestic final goods producers buy intermediate goods from the intermediate goods producers and transform them into a final consumption good using the following production technology:

$$
Y_{j, t}=B_{j, t} X_{j, t}
$$

where $B_{j, t}$ is firm $j$ 's idiosyncratic level of productivity at time $t$ and $X_{j, t}$ is the aggregate input used in the production of $Y_{j, t}$, which is equal to:

$$
X_{j, t}=\left[\left(\frac{1}{2-N^{*}}\right)^{\frac{1}{\theta_{A}}} X_{H, j, t}^{\frac{\theta_{A}-1}{\theta_{A}}}+\left(\frac{1-N^{*}}{2-N^{*}}\right)^{\frac{1}{\theta_{A}}} X_{F, j, t}^{\frac{\theta_{A}-1}{\theta_{A}}}\right]^{\frac{\theta_{A}}{\theta_{A}-1}}
$$

$X_{H, j, t}$ is the aggregate input provided by the Home intermediate goods producers and $X_{F, j, t}$ is the aggregate input provided by the Foreign intermediate goods producers to the final goods producer $j$.

In their production, final goods producers use all varieties of intermediate goods which are available for sale in the domestic economy. $X_{H, j, t}$ is a CES aggregator of all intermediate varieties produced in the Home economy:

$$
X_{H, j, t}=\left[\int_{0}^{1}\left(X_{H, i, j, t}\right)^{\frac{\theta_{A}-1}{\theta_{A}}} d i\right]^{\frac{\theta_{A}}{\theta_{A}-1}}
$$

Similarly, $X_{F, j, t}$ is a CES aggregator of all intermediate varieties produced in the Foreign economy which are exported:

$$
X_{F, j, t}=\left[\int_{N^{*}}^{1}\left(X_{F, i, j, t}\right)^{\frac{\theta_{A}-1}{\theta_{A}}} d i\right]^{\frac{\theta_{A}}{\theta_{A}-1}}
$$

The different varieties are purchased by the final goods producers in proportions which minimize the cost of producing one unit of output $Y_{j, t}$. The total demand for domestic intermediate inputs by the final goods producer $j$ is therefore given by:

$$
X_{H, j, t}=\left(\frac{1}{2-N^{*}}\right)\left(\frac{Q_{H, t}}{Q_{t}}\right)^{-\theta_{A}} X_{j, t}
$$

The total demand for the input provided by foreign intermediate goods producers to the final goods producer $j$ is equal to: 


$$
X_{F, j, t}=\left(\frac{1-N^{*}}{2-N^{*}}\right)\left(\frac{Q_{F, t}}{Q_{t}}\right)^{-\theta_{A}} X_{j, t}
$$

where $X_{j, t}$ is the demand for intermediate inputs by the final goods producer $j$ which is equal to the quantity required to produce the profit-maximizing level of output, $Y_{j, t} . Q_{H, t}$ and $Q_{F, t}$ are the aggregate price indices for the Home and Foreign intermediate goods, respectively. They are equal to the minimum expenditure required to buy one unit of the composite intermediate good $X_{H, t}$ and $X_{F, t}$ given the prices of the different varieties of the intermediate inputs.

The profits of the final goods producer $j$ are given by:

$$
\pi_{j, t}=P_{j, t} C_{j, t}-C_{j, t} \frac{Q_{t}}{B_{j, t}}-F_{B} \frac{W_{t}}{Z_{t}}
$$

The price of the final consumption good produced by firm $j$ at time $t, P_{j, t}$, is set optimally, as a mark-up over marginal cost:

$$
P_{j, t}=\frac{\theta_{B}}{\theta_{B}-1} \frac{Q_{t}}{B_{j, t}}
$$

where $\theta_{B}$ is the elasticity of substitution between final consumption goods and $Q_{t}$ is the aggregate price index for intermediate goods, equal to the minimal cost of a unit of the aggregate input.

The demand for the variety of final consumption good produced by firm $j$, denoted by $C_{j, t}$, is equal to the supply of this variety, $Y_{j, t}$, and is given by:

$$
Y_{j, t}=C_{j, t}=\left(\frac{P_{j, t}}{P_{t}}\right)^{-\theta_{B}} C_{t}
$$

where $C_{t}$ is the aggregate demand for the final consumption good in the domestic economy.

4.2.2.1 Productivity distribution and non-payment risk As with intermediate goods producers, it is assumed that in the final consumption goods sector the firm-specific level of productivity, $B_{t}$, is distributed Pareto with lower bound $B_{\min }$ and shape parameter $k_{B}>\theta_{B}-1$ where $F(B)=1-\left(\frac{B_{\min }}{B}\right)^{k_{B}}$.

The average productivity among all final goods producers, $B_{A}$, can now be defined as:

$$
B_{A}=\left[\int_{B_{\min }}^{\infty} B_{t}^{\theta_{B}-1} d F(B)\right]^{\frac{1}{\theta_{B}-1}}=v_{B} B_{\min }
$$

where $v_{B}=\left[\frac{k_{B}}{k_{B}-\left(\theta_{B}-1\right)}\right]^{\frac{1}{\theta_{B}-1}}$. 
Due to the presence of fixed costs of production and firms' heterogeneity with regard to their productivity, there is a fraction of firms in each period whose revenues from sales are smaller than the total production costs and who are therefore not able to fulfil all their financial obligations. If at the end of the period revenues from sales exceed a firm's total cost, then the firm repays all trade credit due and keeps the remaining profits, which are then passed on to households in the form of dividends. If total costs exceed revenues then the firm declares bankruptcy and receives nothing. The trade credit suppliers receive the firms' revenues net of wages and the advance payment for the intermediate goods made at the beginning of the period.

For any given realization of aggregate shocks, there is a threshold level of firmspecific productivity $\bar{B}_{t}$ above which firms are able to pay all their costs of production, including the cost of intermediate inputs and the fixed production cost. This threshold level of productivity is determined by the condition:

$$
\frac{1}{\theta_{B}-1} Q_{t} \bar{B}_{t}^{\theta_{B}-1} B_{A}^{-\theta_{B}} C_{t}=F_{B} \frac{W_{t}}{Z_{t}}
$$

For the purpose of calculating the trade credit default rate, it is useful to define a threshold level of firm-specific productivity $\bar{B}_{t}$ above which firms are able to pay all their financial obligations apart from trade credit. This threshold productivity level satisfies the condition:

$$
\begin{aligned}
F_{B} \frac{W_{t}}{Z_{t}}= & \bar{B}_{t}^{\theta_{B}-1} C_{t} B_{A}^{-\theta_{B}} Q_{t}^{\theta_{A}} \frac{\theta_{B}}{\theta_{B}-1} Q_{t}^{1-\theta_{A}} \\
& -\overline{\bar{B}}_{t}^{\theta_{B}-1} C_{t} B_{A}^{-\theta_{B}} Q_{t}^{\theta_{A}}\left[\left(1-d_{F}\right)\left(\frac{1-N^{*}}{2-N^{*}}\right) Q_{F, t}^{1-\theta_{A}}\right. \\
& \left.+\left(1-d_{H}\right)\left(\frac{1}{2-N^{*}}\right) Q_{H, t}^{1-\theta_{A}}\right]
\end{aligned}
$$

The default rate on trade credit, $\rho_{t}$, which is defined as the fraction of the total trade credit which is not repaid, is then equal to:

$$
\begin{aligned}
\rho_{t}= & \frac{\int_{B_{\min }}^{\bar{B}_{t}}\left[d_{H} X_{H, j, t} Q_{H, t}+d_{F} X_{F, j, t} Q_{F, t}\right] d F(B)}{\int_{B_{\min }}^{\infty}\left[d_{H} X_{H, j, t} Q_{H, t}+d_{F} X_{F, j, t} Q_{F, t}\right] d F(B)} \\
& -\frac{\int_{\bar{B}_{t}}^{\bar{B}_{t}}\left[Y_{j, t} P_{j, t}-\left(1-d_{H}\right) X_{H, j, t} Q_{H, t}-\left(1-d_{F}\right) X_{F, j, t} Q_{F, t}-F_{B} \frac{W_{t}}{Z_{t}}\right] d F(B)}{\int_{B_{\min }}^{\infty}\left[d_{H} X_{H, j, t} Q_{H, t}+d_{F} X_{F, j, t} Q_{F, t}\right] d F(B)}
\end{aligned}
$$

Given the productivity distribution among final goods producers, the probability that at time $t$ a firm is able to meet all its financial obligations and earn non-negative profits is equal to: 


$$
1-M_{H, t}=1-F\left(\bar{B}_{t}\right)=\left(\frac{B_{\min }}{\bar{B}_{t}}\right)^{k_{B}}
$$

Similarly, the probability that a firm is able to pay for all of its costs of production apart from the trade credit is given by:

$$
1-M_{L, t}=1-F\left(\overline{\bar{B}}_{t}\right)=\left(\frac{B_{\min }}{\overline{\bar{B}}_{t}}\right)^{k_{B}}
$$

In consequence, $M_{H, t}$ is the probability that a firm defaults on at least a fraction of the trade credit received and $M_{L, t}$ is the probability that a firm defaults on the entire value of the trade credit granted to it.

It is now possible to define the following productivity averages. The average productivity among non-defaulting final goods producers who earn non-negative profits after paying all their financial obligations including trade credit is equal to:

$$
B_{H H, t}=\left[\frac{1}{1-F\left(\bar{B}_{t}\right)} \int_{\bar{B}_{t}}^{\infty} B_{t}^{\theta_{B}-1} d F(B)\right]^{\frac{1}{\theta_{B}-1}}=v_{B} \bar{B}_{t}
$$

The average productivity among defaulting final goods producers who default on at least a fraction of their trade credit is given by:

$$
\begin{aligned}
B_{H L, t} & =\left[\frac{1}{F\left(\bar{B}_{t}\right)} \int_{B_{\min }}^{\bar{B}_{t}} B_{t}^{\theta_{B}-1} d F(B)\right]^{\frac{1}{\theta_{B}-1}} \\
& =v_{B}\left[\frac{1}{M_{H, t}} B_{\min }^{\theta_{B}-1}-\frac{\left(1-M_{H, t}\right)}{M_{H, t}}\left(\bar{B}_{t}\right)^{\theta_{B}-1}\right]^{\frac{1}{\theta_{B}-1}}
\end{aligned}
$$

The average productivity among final goods producers who earn non-negative profits after paying all their financial obligations apart from the trade credit is equal to:

$$
B_{L H, t}=\left[\frac{1}{1-F\left(\overline{\bar{B}}_{t}\right)} \int_{\overline{\bar{B}}_{t}}^{\infty} B_{t}^{\theta_{B}-1} d F(B)\right]^{\frac{1}{\theta_{B}-1}}=v_{B} \overline{\bar{B}}_{t}
$$

The average productivity among final goods producers who default on the entire value of the trade credit received is given by: 


$$
\begin{aligned}
B_{L L, t} & =\left[\frac{1}{F\left(\overline{\bar{B}_{t}}\right)_{B_{\min }}} \int_{t}^{\overline{\bar{B}}_{t}} B_{t}^{\theta_{B}-1} d F(B)\right]^{\frac{1}{\theta_{B}-1}} \\
& =v_{B}\left[\frac{1}{M_{L, t}} B_{\min }^{\theta_{B}-1}-\frac{\left(1-M_{L, t}\right)}{M_{L, t}}\left(\overline{\bar{B}}_{t}\right)^{\theta_{B}-1}\right]^{\frac{1}{\theta_{B}-1}}
\end{aligned}
$$

\subsection{Aggregation}

Given the assumptions concerning firms' productivity distribution, it is now possible to express all the aggregate variables and the equilibrium conditions of the model in terms of the productivity averages for the different groups of intermediate and final goods producers which are defined above.

Using the productivity averages defined for firms producing intermediate goods, the aggregate price index for these goods produced and sold in the Home economy is equal to:

$$
Q_{H, t}=\frac{\theta_{A}}{\theta_{A}-1} \frac{W_{t}}{Z_{t} A_{A}} g_{H, t}
$$

Similarly, the price index for domestically produced intermediate inputs which are sold in the Foreign market is given by:

$$
Q_{F, t}^{*}=(1+\tau) \frac{\theta_{A}}{\theta_{A}-1} \frac{W_{t}}{Z_{t} A_{E, t}} g_{F, t}^{*} \frac{1}{S_{t}}
$$

The aggregate supply of the domestically produced intermediate goods sold on the domestic market, $V_{H, t}$, can be expressed as a function of the average level of productivity in the Home market, equal to $Z_{t} A_{A}$, and the aggregate labor supply used in the production of these goods, $L_{H, t}$ :

$$
V_{H, t}=Z_{t} A_{A} L_{H, t}
$$

where:

$$
L_{H, t}=\int_{0}^{1} L_{H, i, t} d i
$$

In turn, the aggregate supply of the domestically produced intermediate goods which are exported, $V_{F, t}$, can be expressed as a function of the average level of productivity among domestic exporters, equal to $Z_{t} A_{E}$, and the aggregate labor supply used in the production of these goods, $L_{F, t}$ : 


$$
V_{F, t}=Z_{t} A_{E, t} L_{F, t}
$$

where:

$$
L_{F, t}=\int_{0}^{1} L_{F, i, t} d i
$$

Using the productivity averages for the producers of final consumption goods, the aggregate supply of the final consumption good in the Home economy, $Y_{t}$, can be expressed as:

$$
Y_{t}=B_{A} X_{t}
$$

The aggregate price index for the final consumer goods in the Home economy is equal to:

$$
P_{t}=\frac{\theta_{B}}{\theta_{B}-1} \frac{Q_{t}}{B_{A}}
$$

The aggregate demand for intermediate goods in the Home economy, $X_{t}$, can be expressed as a function of the aggregate demand for domestically produced intermediate goods, $X_{H, t}$, and the aggregate demand for the intermediate goods which are imported, $X_{F, t}$ :

$$
X_{t}=\left[\left(\frac{1}{2-N^{*}}\right)^{\frac{1}{\theta_{A}}} X_{H, t}^{\frac{\theta_{A}-1}{\theta_{A}}}+\left(\frac{1-N^{*}}{2-N^{*}}\right)^{\frac{1}{\theta_{A}}} X_{F, t}^{\frac{\theta_{A}-1}{\theta_{A}}}\right]^{\frac{\theta_{A}}{\theta_{A}-1}}
$$

where:

$$
\begin{aligned}
& X_{H, t}=\left[\int_{0}^{1}\left(X_{H, i, t}\right)^{\frac{\theta_{A}-1}{\theta_{A}}} d i\right]^{\frac{\theta_{A}}{\theta_{A}-1}}=\left(\frac{1}{2-N^{*}}\right)\left(\frac{Q_{H, t}}{Q_{t}}\right)^{-\theta_{A}} X_{t} \\
& X_{F, t}=\left[\int_{N}^{1}\left(X_{F, i, t}\right)^{\frac{\theta_{A}-1}{\theta_{A}}} d i\right]^{\frac{\theta_{A}}{\theta_{A}-1}}=\left(\frac{1-N^{*}}{2-N^{*}}\right)\left(\frac{Q_{F, t}}{Q_{t}}\right)^{-\theta_{A}} X_{t}
\end{aligned}
$$

Using the definitions of average productivity levels among different categories of final goods producers, the trade credit default rate can be expressed as: 


$$
\begin{aligned}
\rho_{t}= & \frac{M_{H, t} B_{H, t}^{\theta_{B}-1}+\left(\bar{B}_{t}-\overline{\bar{B}}_{t}\right) F_{B} \frac{W_{t}}{Z_{t}} \frac{1}{Q_{t} C_{t}} B_{A}^{\theta_{B}}}{\left[d_{H}\left(\frac{1}{2-N^{*}}\right) Q_{H, t}^{1-\theta_{A}}+d_{F}\left(\frac{1-N^{*}}{2-N^{*}}\right) Q_{F, t}^{1-\theta_{A}}\right] B_{A}^{\theta_{B}-1} Q_{t}^{\theta_{A}-1}} \\
& -\frac{\left[\left(1-d_{H}\right)\left(\frac{1}{2-N^{*}}\right) Q_{H, t}^{1-\theta_{A}}+\left(1-d_{F}\right)\left(\frac{1-N^{*}}{2-N^{*}}\right) Q_{F, t}^{1-\theta_{A}}\right] Q_{t}^{\theta_{A}-1} M_{L, t} B_{L L, t}^{\theta_{B}-1}}{\left[d_{H}\left(\frac{1}{2-N^{*}}\right) Q_{H, t}^{1-\theta_{A}}+d_{F}\left(\frac{1-N^{*}}{2-N^{*}}\right) Q_{F, t}^{1-\theta_{A}}\right] B_{A}^{\theta_{B}-1} Q_{t}^{\theta_{A}-1}} \\
& -\frac{\frac{\theta_{B}}{\theta_{B}-1}\left(M_{H, t} B_{H L, t}^{\theta_{B}-1}-M_{L, t} B_{L L, t}^{\theta_{B}-1}\right)}{\left[d_{H}\left(\frac{1}{2-N^{*}}\right) Q_{H, t}^{1-\theta_{A}}+d_{F}\left(\frac{1-N^{*}}{2-N^{*}}\right) Q_{F, t}^{1-\theta_{A}}\right] B_{A}^{\theta_{B}-1} Q_{t}^{\theta_{A}-1}}
\end{aligned}
$$

\subsection{Resource constraints}

Equilibrium in the goods market requires that in each country the supply of intermediate goods produced for the domestic and foreign market is equal to the demand for these goods in the Home and Foreign economy: $V_{H, t}=X_{H, t}$ and $V_{F, t}=X_{F, t}^{*}$. Similarly, the supply needs to be equal to demand in the sector of final consumption goods: $Y_{t}=C_{t}$.

Labor market equilibrium requires that in each country the labor employed in the production of intermediate goods and the labor employed to cover the fixed costs of producing final consumption goods and exporting is equal to the domestic labor supply:

$$
L_{t}=L_{H, t}+L_{F, t}+\frac{1}{Z_{t}}\left[F_{B}+\left(1-N_{t}\right) F_{A}\right]
$$

The model is closed by normalizing the Home price index of the final consumption goods to one: $P_{t}=1$ and by setting the nominal exchange rate equal to one: $S_{t}=1 .{ }^{18}$

\section{Parametrization}

The model is calibrated assuming that one period of time corresponds to one quarter. The calibration of preference parameters determining households' utility function follows the international business cycle literature. Both the inverse of the intertemporal elasticity of substitution in consumption, $\sigma$, and the inverse of the Frisch elasticity of labor supply, $\varphi$, are set equal to 2.0. The discount factor is set to $\beta=0.99$. The elasticity of substitution between different varieties in both the sectors of intermediate goods and final consumption goods is equal to $\theta_{A}=\theta_{B}=6$ to give a mark-up of 20 percent, as in Obstfeld and Rogoff (2001). Following Obstfeld and

\footnotetext{
18 A complete set of the model's equilibrium conditions for the Home economy are presented in Appendix A.1.
} 
Rogoff (2001), Ravn and Mazzenga (2004) and Anderson and van Wincoop (2004), the iceberg trade $\operatorname{cost} \tau$ is parametrized to be equal to 20 percent of the value of goods exported.

It is assumed that the distribution of firm-specific productivity is the same in both the sector for intermediate goods and the sector for final consumption goods. The parameters $k_{A}$ and $k_{B}$ governing the dispersion of productivity levels among firms are set equal to $k_{A}=k_{B}=6.25$, which is in line with empirical evidence on the distribution of firms' size (Axtell, 2001). The lower bound for idiosyncratic productivity is set equal to one, $A_{\min }=1$. The fixed production costs in the sector of final consumption goods, $F_{B}$, are calibrated to match the default rate on accounts payables/receivables, which Boissay and Gropp (2007) estimate to be equal to 2 percent, based on French firm-level data. The fixed cost of exporting, $F_{A}$, is set to match a share of exporters among the intermediate goods producers equal to 35 percent, which is the average share of exporters among the top 15,000 manufacturing firms in the UK and Ireland in the period 2003-2014, based on Fame data.

The fractions of trade credit to total sales revenues granted to domestic and foreign buyers are set equal to $d_{H}=0.55$ and $d_{F}=0.75$ respectively, to match the empirical evidence for UK and Irish firms discussed in Sect. 3 of this paper. Among the top 1000 of British and Irish manufacturing firms, which cover 82 percent of total manufacturing revenues and therefore reflect well the use of trade credit by firms which determine aggregate macroeconomic fluctuations, the average ratios of trade debtors to revenues among exporters and non-exporters in the period from 2003 to 2014 were equal to 12.6 and 9.1 percent respectively. Assuming that the average duration of trade credit is 2 months, as demonstrated by Klapper et al. (2012), non-exporting firms sell 55 per cent of their goods on trade credit, while firms engaged in international trade extend trade credit for 76 percent of their sales. ${ }^{19}$ The values of all the model parameters adopted in the analysis are listed in Table 4 in Appendix A.2.

\section{Results}

This section examines the impact of trade credit on business cycle fluctuations by tracing the responses of key macroeconomic variables to demand and productivity shocks and by investigating the properties of the business cycles generated by the model developed in Sect. 4. In order to illustrate the way in which trade credit alters the transmission of shocks in the economy and business cycle fluctuations, three different versions of the model are compared: the baseline model (BS) in which there

\footnotetext{
19 In the same time period, the average ratios of trade debtors to revenues for exporters and non-exporters among the top 5000 of all firms, which cover about 87 percent of total revenues, were very similar and were equal to 12.7 and 9.2 percent respectively, which also corresponds to the fractions of goods sold on trade credit of 76 and 55 percent respectively.
} 

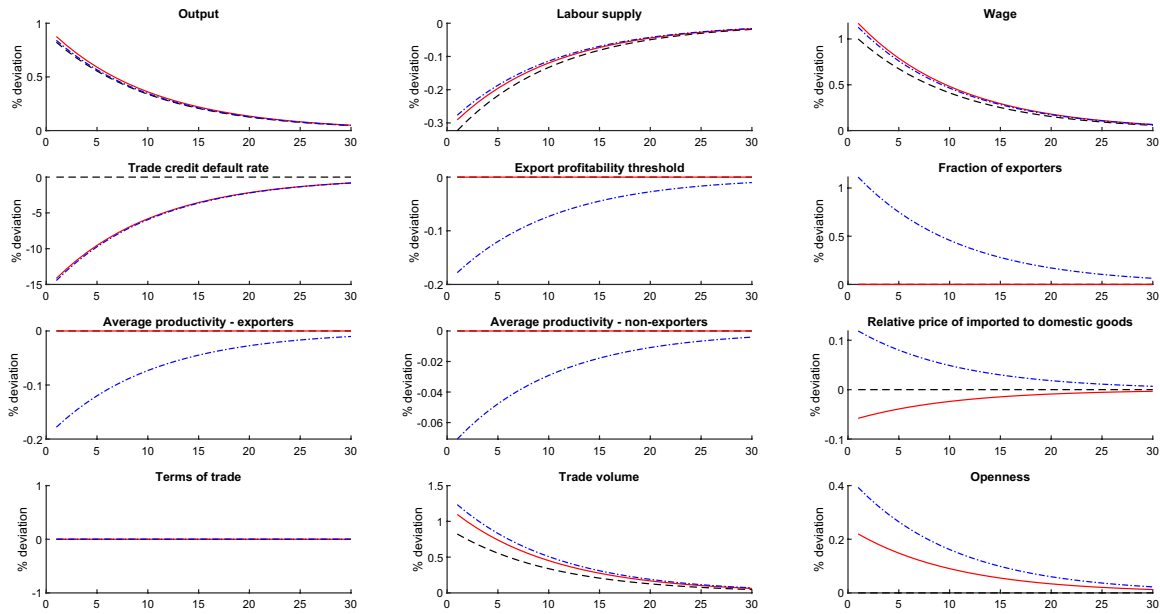

- - - - Baseline model (BS) ——Trade credit model (TC) -.-.-...Trade credit model with extensive margin (TCM)

Fig. 1 Impulse responses to a 1 percent positive symmetric productivity shock in the sector producing intermediate goods

is no trade credit and in which the fraction of internationally traded varieties is constant over time, the trade credit model (TC), which extends the baseline model by introducing inter-firm lending, and the trade credit model with extensive margin of trade (TCM), which features both inter-firm lending and endogenous entry into the exports market. ${ }^{20}$ The comparison of the different versions of the model makes it possible to examine the contributions of trade credit and of the extensive margin of trade to changes in the volume of international trade in response to shocks.

\subsection{Impulse responses}

\subsubsection{Symmetric shocks}

In order to understand the impact of trade credit and the associated counterparty risk on the fluctuations of international trade relative to output, it is useful to examine the effects of macroeconomic shocks which are symmetric across countries.

6.1.1.1 Productivity shocks Figure 1 compares the effects of a one percent positive symmetric productivity shock in the intermediate goods sector in the BS model, the TC model and the TCM model. It shows that the use of trade credit by firms can

\footnotetext{
${ }^{20}$ The TCM model nests both the TC and the BS models. In the TC model the fraction of non-exporting firms is set to $N=0.65$ and is constant over time. In the BS model, in addition to the above restriction, the fraction of sales for which trade credit is granted is set equal to zero: $d_{H}=d_{F}=0$, as is the trade credit default rate: $\rho=0$. The parameterization of all three versions of the model used in the analysis is presented in Appendix A.2.
} 
lead to significant differences in the impact of macroeconomic shocks on international trade. A favorable shock raising the productivity level of intermediate goods producers in both the Home and the Foreign economy leads to an increase in output and consumption in all three models analyzed. The increase in output is to some extent dampened by a reduction in labor supply which results from an increase in real wages and the fact that as the intertemporal elasticity of substitution in consumption is smaller than one, the income effect dominates the substitution effect.

The behavior of the relative prices of intermediate goods sold in the domestic and in the foreign market differs substantially in the three models analyzed. In the BS model, the average price of these goods remains constant regardless of their destination market, as the increase in the marginal product of labor is offset by an equal increase in real wages.

In the TC model taking trade credit into account, a favorable productivity shock increases output and firms' profits and reduces the default rate among the producers of final consumption goods. The decline in the risk of non-repayment associated with trade credit leads to a decrease in the marginal costs and in the prices of the producers of intermediate inputs. As trade credit is more intensively used in international than in domestic transactions, the fall in the marginal cost is relatively larger for goods sold in the foreign market. As a result, in the presence of inter-firm lending the relative price of intermediate inputs sold abroad declines as compared to the price of intermediate inputs sold domestically.

In the TCM model in which the decision to export is endogenous, an increase in the aggregate level of productivity reduces the threshold idiosyncratic productivity level above which exporting is profitable and, as a result, the share of exporting firms among the intermediate goods producers increases. ${ }^{21}$ In the TCM model, the productivity shock leads to an increase in the average price of intermediate inputs sold in the foreign market relative to the average price of the intermediate inputs sold domestically. This is due to the fact that the decline in the export profitability threshold, $\bar{A}_{t}$, and the increase in the share of exporting firms following the rise in aggregate productivity reduce the average level of idiosyncratic productivity among exporters, $A_{E, t}$, by more than they reduce the average firm-specific productivity level among non-exporters, $A_{N, t}$. Despite the fact that the reduction in the trade credit default rate puts a downward pressure on the relative price of intermediate inputs sold abroad as compared to the price of intermediate inputs sold domestically, the overall impact of the productivity shock on the relative price of foreign to domestic intermediate goods is positive.

Changes in aggregate demand, the share of exporting firms and the relative price of imported and domestic intermediate goods which follow the productivity shock lead to changes in the volume of international trade. The increase in trade caused by a rise in aggregate productivity is smallest in the benchmark model (BS) and largest in the model with trade credit and the extensive margin of trade (TCM).

\footnotetext{
${ }^{21}$ The increase in trade along the extensive margin is greater in the presence of inter-firm lending than without it due to the decline in the foreign market price of each internationally traded intermediate input relative to its domestic market price caused by a reduction in the trade credit default rate.
} 
In the BS model, in which the share of exporting firms is constant and in which the relative price of foreign and domestic goods is unaffected by the productivity shock, the only factor influencing international trade is aggregate demand. As a result, the percentage increase in trade following the shock is the same as the percentage increase in output and the trade income elasticity is equal to one. ${ }^{22}$

In the TC model, the impact of the productivity shock on trade is larger than its impact on output due to the changes in the relative foreign and domestic market price of intermediate inputs resulting from lower riskiness of inter-firm lending. The fall in the relative price of imported goods as compared to domestic goods caused by the reduction in the trade credit default rate leads to an increase in the demand for intermediate inputs produced abroad relative to the demand for intermediate inputs of domestic origin. The increase in trade volume in the TC model is considerably higher than in the baseline model without inter-firm lending - the trade income elasticity is equal to 1.25 .

In the TCM model, the impact of the productivity shock on trade is even larger. This is due to the changes in the fraction of intermediate goods producers exporting their goods and the resulting changes in the composition of the consumption basket of final goods producers who purchase all varieties of intermediate inputs available for sale in the domestic economy. Following the shock, the number of foreign varieties available on the domestic market increases compared to the number of varieties produced domestically. As a result, the share of imported goods in the consumption basket increases for any given relative price of domestic and imported goods-there is an endogenous decline in the home bias of final goods producers. While there is an increase in the relative average price of intermediate inputs of foreign origin as compared to those of domestic origin, this is entirely due to the fact that the new foreign varieties available for sale in the domestic market have a relatively higher average price than the foreign varieties traded initially. For any variety sold both in the domestic and in the foreign market, its relative price on the foreign market decreases due to the reduction in the trade credit default rate. The increase in the number of internationally traded varieties combined with a decline in the foreign market price of each variety as compared to its domestic market price leads to an increase in the share of imported intermediate inputs in the production of final consumption goods and a rise in international trade which significantly exceeds the increase in output. The elasticity of real trade to real income in this model is equal to 1.47.

The productivity shock has different implications for trade openness, defined as the ratio of the sum of imports and exports to output, in the three models analyzed. In the BS model openness remains unchanged, while in the TC and TCM models it increases following the shock, with the increase being largest in the TCM model accounting for both trade credit and the extensive margin of trade.

\footnotetext{
22 The trade income elasticity is calculated as the percentage deviation of real world trade from its steady state divided by the percentage deviation of real world output from its steady state. It is the same for each period following the shock.
} 
6.1.1.2 Demand shocks The impact of a one percent positive symmetric demand shock on international trade, which is illustrated in Fig. 2, is similar to that of a favorable productivity shock. An exogenous increase in the marginal utility of consumption for any given consumption level leads to an increase in aggregate demand and output in the economy. Labor supply increases as the marginal utility of leisure declines for any level of work effort.

In the TC model, which takes trade credit into account, the positive demand shock reduces the riskiness of inter-firm lending. Due to the relatively more intensive use of trade credit in international transactions, the decline in trade credit default rate has a larger impact on the foreign market price of each traded variety than on its domestic market price. This leads to a decline in the price of imported intermediate inputs relative to the price of intermediate inputs produced domestically and to an increase in the demand for foreign goods as compared to domestic goods. As a result, there is an increase in trade along the intensive margin which is larger than the increase in output.

In the TCM model, which additionally accounts for endogenous entry into the exports market, the demand shock causes similar changes in the relative prices of imported and domestic varieties as well as their weights in the consumption aggregator of the final goods producers as a favorable productivity shock. The increase in aggregate demand induced by the shock, as well as the associated decline in the trade credit default rate, raises the profitability of exporting and the share of exporters among intermediate goods producers. In consequence, there is an increase in international trade along both the intensive and the extensive margins and the increase in trade significantly exceeds that of output.

Changes in wages are small and differ across the three models considered. Profit maximization on the part of intermediate goods producers requires that the real wage is equal to the real marginal revenue product of labor. In the BS model, the wage rate is constant as the marginal revenue product of labor does not change. In
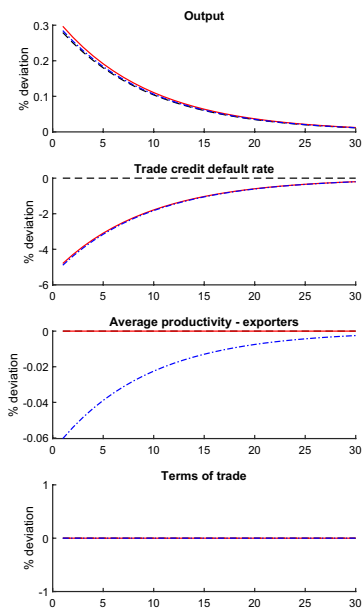

- - - Baseline model (BS)
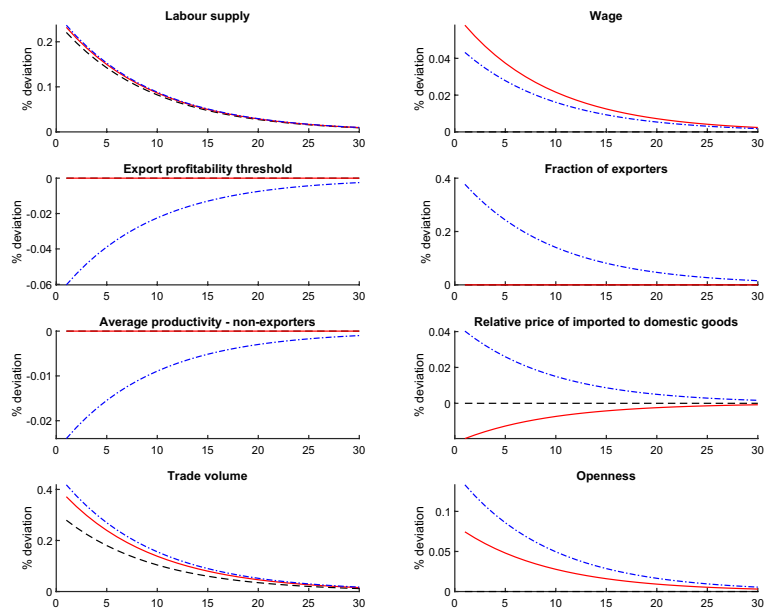

-Trade credit model (TC) -..... Trade credit model with extensive margin (TCM)

Fig. 2 Impulse responses to a 1 percent positive symmetric demand shock 
the TC model the marginal revenue product of labor depends on the trade credit default rate, which declines following the shock leading to an increase in the wage rate. In the TCM model the increase in the wage rate is dampened due to the fact that an increase in the percentage of internationally traded varieties following the shock leads to a decline in the average price charged by intermediate goods producers.

As in the case of the productivity shock, the trade income elasticities generated by the BS, TC and TCM models are equal to $1.00,1.25$ and 1.47 respectively. Trade openness in the BS model is constant, while it increases in both the TC and the TCM models accounting for inter-firm lending.

\subsubsection{Asymmetric shocks}

The analysis in the previous section showed that trade credit amplifies the effects of macroeconomic shocks on international trade along both the intensive and the extensive margins even if shocks are symmetric across countries and have no impact on international relative prices - the real exchange rate and the terms of trade. Interfirm lending also alters the effects of macroeconomic shocks when they are countryspecific. In the case of asymmetric shocks, changes in macroeconomic conditions and the resulting changes in the counterparty risk associated with trade credit affect not only the relative domestic and foreign market price of traded varieties but also the relative export price of intermediate inputs produced at home and abroad.

6.1.2.1 Productivity shocks Figure 3 shows the effects of a one percent positive productivity shock in the sector producing intermediate goods in the Home economy. Through the risk sharing mechanism the shock leads to an increase in output and consumption in both countries in all three models considered. The rise in output is higher in the Home than in the Foreign economy. The effect of the shock on labor supply in
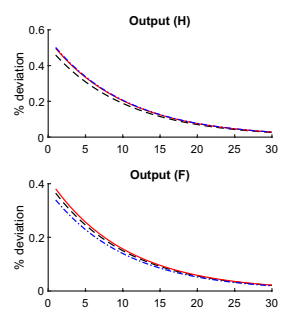

Fraction of exporters (H)
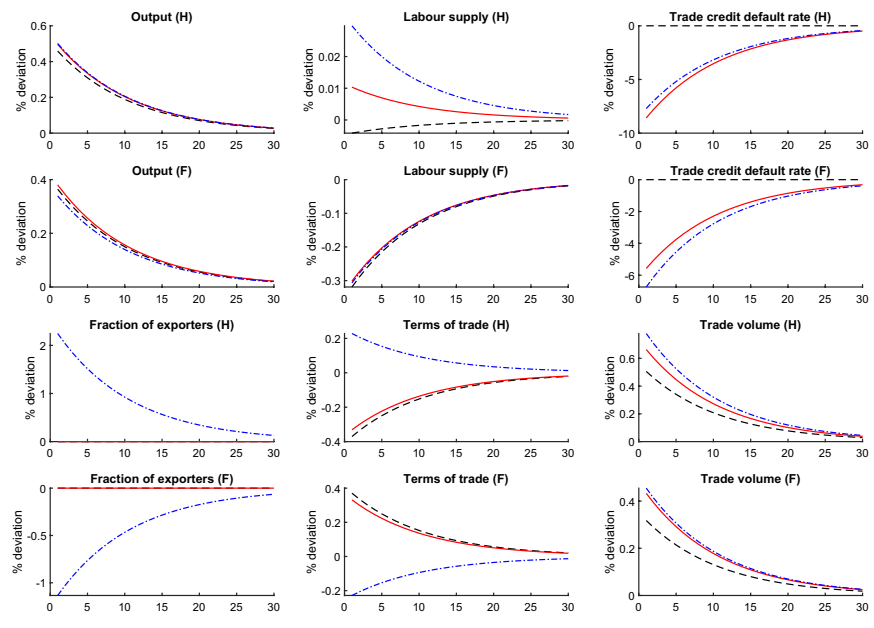

Trade volume (H)

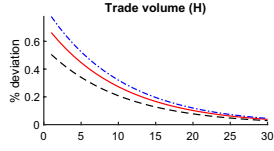

Trade volume (F)
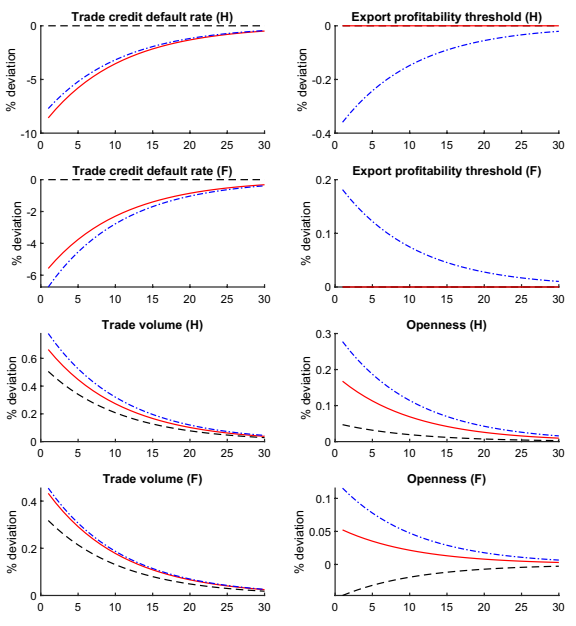

Fig. 3 Impulse responses to a 1 percent positive productivity shock in the sector producing intermediate goods in the Home economy 
the Foreign economy is unambiguously negative whereas in the Home economy it differs across the models, reflecting differences in the relative strength of the income and substitution effects.

The impact of the shock on international trade varies significantly across the three models. In the BS model, an increase in productivity in the Home economy lowers the relative price of internationally traded goods produced in this economy and leads to a depreciation of the terms of trade. There is an increase in the market share of Home exporters in the Foreign economy, while the market share of Foreign exporters in the Home economy decreases. In consequence, in the Home economy trade volume increases more than output by a factor of 1.10. In the Foreign economy the percentage increase in trade corresponds to 0.87 of the percentage output increase. Hence, a rise in trade openness in the Home economy is accompanied by a decline in trade openness in the Foreign economy.

In the TC model, the favorable productivity shock reduces the trade credit default rates among both Home and Foreign producers, leading to a decrease in the foreign market price of each internationally traded variety as compared to its domestic market price. This contributes to a rise in the share of imported inputs in the production of final consumption goods and to an increase in trade volume in both economies. In both countries the increase in imports and exports exceeds that of output (by a factor of 1.34 in the Home economy and 1.14 in the Foreign economy), and there is a rise in trade openness.

In the TCM model, the productivity shock leads additionally to changes in the number of traded varieties and movements in international trade along the extensive margin. In the Home economy, the share of exporters increases both due to higher aggregate demand abroad and an improvement in the competitiveness of Home producers on the Foreign market. In the Foreign economy the positive impact that an increase in aggregate demand abroad exerts on exports profitability is more than offset by a fall in the relative demand for Foreign versus Home goods and there is a decline in the number of Foreign varieties which are exported. Due to the resulting changes in the average productivity of exporters in both economies, the average price of Home exports increases as compared to the average price of Home imports, leading to an appreciation of the terms of trade in the Home economy. ${ }^{23}$ However, changes in the relative number and price of domestic and foreign intermediate goods in both countries, exacerbated by the changes in the trade credit default rates, lead to an increase in the share of imported inputs in the consumption basket of final goods producers. In the Home economy, the increase in trade following the shock is 1.55 times larger than the increase in output, while in the Foreign economy the increase in trade is 1.34 times larger than the increase in output. As the asymmetric productivity shock leads to a significant increase in trade volume relative to output in both countries, both countries experience a rise in trade openness.

\footnotetext{
23 This result is in line with the findings of a number of studies showing that in models accounting for the extensive margin of trade an increase in a country's productivity can have a positive impact on the country's terms of trade (Corsetti et al., 2007; Ghironi \& Melitz, 2005; Krugman, 1989). It is also consistent with theoretical and empirical evidence provided by Corsetti et al. (2008).
} 
6.1.2.2 Demand shocks A one percent favorable demand shock in the Home economy, which is illustrated in Fig. 4, leads to an increase in consumption and output in the country affected directly by the shock and a decline in consumption and output abroad. Labor supply increases in both countries. In the Home economy this is due to the exogenous increase in marginal utility of consumption for any consumption level. In the Foreign economy it results from the increase in the marginal utility of consumption associated with the fall in the level of income.

In the BS model, an increase in consumption in the Home economy relative to the Foreign economy leads to an appreciation of the terms of trade. The decline in the level of aggregate demand in the Foreign economy reduces exports at Home. This is more than offset by a rise in imports and overall there is an increase in trade. However, as the percentage increase in trade volume in the Home economy is only equivalent to 0.33 of the percentage increase in output, trade openness falls. In contrast, in the Foreign economy an increase in exports exceeds a decline in imports and there is a rise in trade volume while output decreases, which leads to higher trade openness.

In the TC model, the demand shock causes diverging changes in the default rates among firms in the Home and Foreign economies; the latter increases while the former declines. This puts an additional upward pressure on terms of trade at Home. There is a further increase in trade volume in the Home economy, which now corresponds to 0.54 of the percentage output increase, leading to a smaller decline in trade openness. In the Foreign economy there is a slight increase in trade openness as compared to the BS model.

In the TCM model, the demand shock reduces the fraction of exporters among intermediate goods producers in the Home economy due to a decline in aggregate demand in the Foreign economy and an increase in the trade credit default rate among Foreign producers. In contrast, the share of exporters among Foreign firms increases. The resulting changes in the average productivity of exporters in both countries exert a depreciation pressure on the terms of trade in the Home economy.
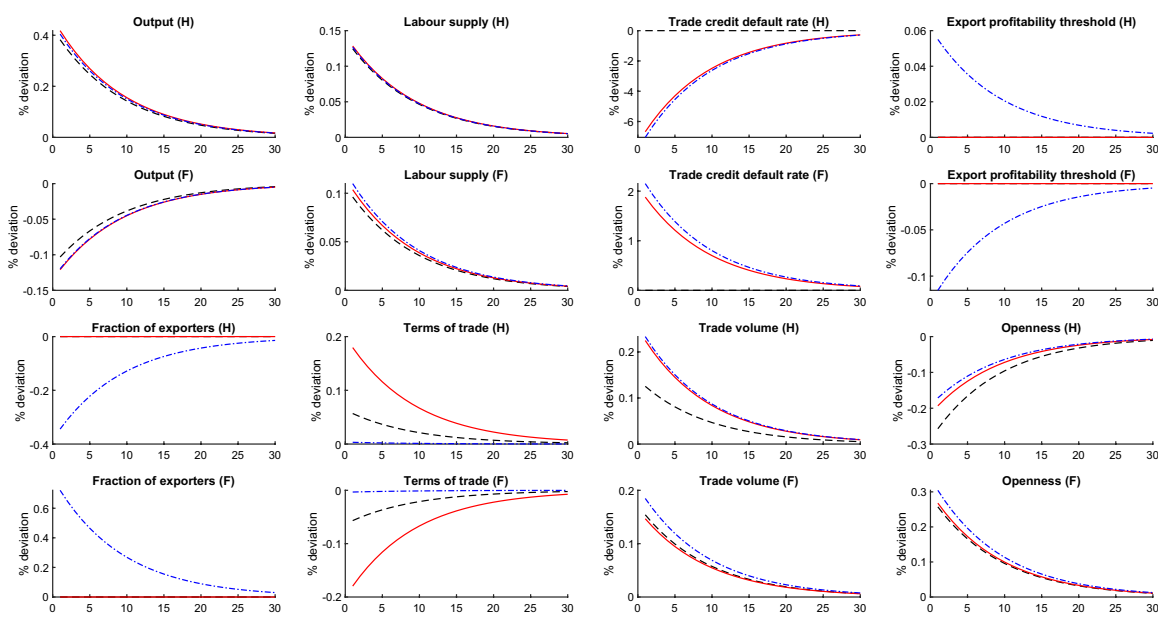

- - - - Baseline model (BS) —— Trade credit model (TC) -.-.-.. Trade credit model with extensive margin (TCM)

Fig. 4 Impulse responses to a 1 percent positive demand shock in the Home economy 
Overall, changes in relative prices, the number of internationally traded varieties and aggregate demand result in a percentage increase in trade volume in the Home economy equivalent to 0.58 of the percentage increase in Home output, leading to a smaller decline in trade openness than in models which do not take endogenous entry into the exports market into account. In the Foreign economy, changes in trade along the extensive margin result in an even greater increase in trade openness as compared to the BS and TC models.

\subsection{Model simulations}

In order to explore further the extent to which trade credit can help explain key features of international trade fluctuations, the international business cycle properties of models incorporating inter-firm lending are compared to those obtained from a model not taking trade credit into account as well as to the data. As before, the analysis is based on business cycle simulations of three different versions of the openeconomy model presented in Sect. 4: the baseline model (BS) with no trade credit and no endogenous entry into the exports market, the trade credit model (TC) with inter-firm lending but no endogenous entry and the trade credit model with extensive margin of trade (TCM). As in Jiang (2016), each of these models is simulated based on two alternative assumptions with regard to the source of business cycle fluctuations. It is first assumed that business cycles are driven by productivity shocks only and then the simulations are performed based on the assumption that business cycles are driven solely by demand shocks.

In this section, for the purpose of the simulations, it is assumed that the productivity shocks in the Home and Foreign economies, denoted by $z_{t}$ and $z_{t}^{*}$ respectively, follow the bivariate process:

$$
\left[\begin{array}{c}
z_{t} \\
z_{t}^{*}
\end{array}\right]=\left[\begin{array}{cc}
\psi_{z} & \psi_{z z^{*}} \\
\psi_{z^{*} z} & \psi_{z^{*}}
\end{array}\right]\left[\begin{array}{c}
z_{t-1} \\
z_{t-1}^{*}
\end{array}\right]+\left[\begin{array}{c}
\zeta_{t}^{z} \\
\zeta_{t}^{z^{*}}
\end{array}\right]
$$

Following Ghironi and Melitz (2005) and Jiang (2016), the persistence parameters are set to: $\psi_{z}=\psi_{z^{*}}=0.906$ and $\psi_{z z^{*}}=\psi_{z^{*} z}=0.088$, the standard deviations of the productivity innovations, $\zeta_{t}^{z}$ and $\zeta_{t}^{z^{*}}$, are set to $\phi_{z}=\phi_{z^{*}}=0.00852$ and the correlation coefficient to $\kappa_{\zeta_{t}^{z}}, \zeta_{t}^{z^{*}}=0.288$, which corresponds to the estimates obtained by Backus et al. (1992).

In simulations where business cycles are driven by demand shocks, it is assumed that the preference shocks in the Home and Foreign economies, represented by $u_{t}$ and $u_{t}^{*}$ respectively, follow the bivariate process given by:

$$
\left[\begin{array}{c}
u_{t} \\
u_{t}^{*}
\end{array}\right]=\left[\begin{array}{cc}
\psi_{u} & \psi_{u u^{*}} \\
\psi_{u^{*} u} & \psi_{u^{*}}
\end{array}\right]\left[\begin{array}{c}
u_{t-1} \\
u_{t-1}^{*}
\end{array}\right]+\left[\begin{array}{c}
\zeta_{t}^{u} \\
\zeta_{t}^{u^{*}}
\end{array}\right]
$$

As in Jiang (2016), the persistence parameters are set to: $\psi_{u}=\psi_{u^{*}}=0.896$ and $\psi_{u u^{*}}=\psi_{u^{*} u}=0.1038$, the standard deviations of the demand innovations, $\zeta_{t}^{u}$ and $\zeta_{t}^{u^{*}}$, are set to $\phi_{u}=\phi_{u^{*}}=0.015$ and the correlation coefficient to $\kappa_{\zeta_{t}^{u}}, \zeta_{t}^{u^{*}}=0.3647$. 
Table 3 International trade statistics and model predictions

\begin{tabular}{|c|c|c|c|c|c|c|}
\hline & \multirow{2}{*}{$\begin{array}{l}\text { Std dev } \\
\mathrm{Y}\end{array}$} & \multicolumn{5}{|c|}{ Std dev relative to output } \\
\hline & & IM & EX & TVOL & OPEN & NXR \\
\hline \multicolumn{7}{|l|}{ Data } \\
\hline US & 1.56 & 3.08 & 3.01 & 2.51 & 1.82 & 0.22 \\
\hline UK & 1.98 & 2.07 & 1.83 & 1.74 & 1.24 & 0.35 \\
\hline \multicolumn{7}{|c|}{ Baseline model (BS) } \\
\hline Productivity & 1.93 & 1.55 & 1.69 & 1.00 & 0.04 & 0.62 \\
\hline Demand & 1.49 & 1.22 & 1.24 & 0.89 & 0.45 & 0.41 \\
\hline \multicolumn{7}{|c|}{ Trade credit model (TC) } \\
\hline Productivity & 2.05 & 1.67 & 1.82 & 1.25 & 0.26 & 0.58 \\
\hline Demand & 1.59 & 1.42 & 1.33 & 1.11 & 0.44 & 0.38 \\
\hline \multicolumn{7}{|c|}{ Trade credit model with extensive margin (TCM) } \\
\hline Productivity & 1.97 & 1.90 & 2.10 & 1.47 & 0.47 & 0.65 \\
\hline \multirow[t]{3}{*}{ Demand } & 1.53 & 1.61 & 1.55 & 1.30 & 0.58 & 0.43 \\
\hline & & \multicolumn{5}{|c|}{ Correlation with output } \\
\hline & & $\mathrm{IM}$ & $\mathrm{EX}$ & TVOL & OPEN & NXR \\
\hline \multicolumn{7}{|l|}{ Data } \\
\hline US & & 0.78 & 0.50 & 0.79 & 0.54 & -0.38 \\
\hline UK & & 0.75 & 0.53 & 0.72 & 0.20 & -0.34 \\
\hline \multicolumn{7}{|c|}{ Baseline model (BS) } \\
\hline Productivity & & 0.57 & 0.61 & 1.00 & 0.05 & 0.05 \\
\hline Demand & & 0.96 & 0.27 & 0.86 & -0.45 & -0.45 \\
\hline \multicolumn{7}{|c|}{ Trade credit model (TC) } \\
\hline Productivity & & 0.67 & 0.70 & 1.00 & 0.99 & 0.06 \\
\hline Demand & & 0.98 & 0.41 & 0.90 & 0.01 & -0.47 \\
\hline \multicolumn{7}{|c|}{ Trade credit model with extensive margin (TCM) } \\
\hline Productivity & & 0.68 & 0.73 & 1.00 & 1.00 & 0.08 \\
\hline Demand & & 0.99 & 0.41 & 0.88 & 0.24 & -0.47 \\
\hline
\end{tabular}

This table shows the empirical and predicted standard deviations of output (Y) as well as the standard deviations relative to output and correlations with output of a number of variables including imports (IM), exports $(\mathrm{EX})$, trade volume $(\mathrm{TVOL}=\mathrm{IM}+\mathrm{EX})$, trade openness $(\mathrm{OPEN}=(\mathrm{IM}+\mathrm{EX}) / \mathrm{Y})$ and the net export ratio $(\mathrm{NXR}=(\mathrm{EX}-\mathrm{IM}) / \mathrm{Y})$. The empirical moments are calculated based on quarterly data for the US and the UK for the sample period from Q1 1955 to Q4 2020. All series are in real terms. The source of the data is OECD Economic Outlook database. All the empirical statistics refer to the cyclical components obtained after applying the HP filter to the natural log of each series (apart from net exports for which no logarithmic transformation is made), with smoothing parameter of 1600 . The predicted moments of all the variables for each of the three versions of the model correspond to averages obtained from 1000 simulations of length 100, where business cycles are driven either by productivity or by demand shocks

Table 3 shows the predicted moments of a number of key variables associated with international trade obtained from 1000 simulations of each of the models BS, TC and TCM with the assumption that business cycles are driven either by productivity shocks or by demand shocks only. The table also reports the empirical moments of 
these variables for the US and for the UK based on quarterly data over the period from Q1 1955 to Q4 2020. The statistics indicate that trade credit plays an important role in explaining cyclical fluctuations in international trade.

The data for the UK and for the US demonstrate some well-documented facts with regard to the dynamics of international trade over the business cycle. Imports and exports are strongly procyclical and much more volatile that output, with imports being more strongly correlated with output than exports. Trade volume, which is measured as the sum of imports and exports in the domestic economy, and trade openness, which is defined as the ratio of trade volume to output, are both also procyclical with their standard deviations significantly exceeding that of output. Net exports are countercyclical.

The BS model, which does not take trade credit nor the extensive margin of trade into account, is unable to replicate many features of the data. Both in the case when business cycles are generated by productivity shocks and when they are attributed to demand shocks, the volatilities of imports, exports and, in particular, the volatility of the trade volume predicted by the model are significantly lower than those observed empirically. The dynamics of trade openness implied by the model are even more at odds with the data. In the model with productivity shocks, openness is acyclical and nearly constant over time, while in the model with demand shocks openness is countercyclical, in contrast to the procyclical and highly volatile openness evident from the data.

Accounting for trade credit greatly contributes to explaining the empirical observations. The TC model incorporating inter-firm lending into the baseline model without taking into account the extensive margin of trade generates significantly higher volatilities of imports, exports and trade volume both in the case of business cycles driven by productivity and demand shocks. It also offers substantial improvement in matching empirical moments of trade openness. In the case of productivity shocks, it predicts procyclical and volatile openness, as observed in the data. In the case of demand shocks it changes the predicted correlation of openness with output from a low negative value obtained in the baseline model, to a small positive value, which brings it closer to those observed in reality.

Accounting for both trade credit and the extensive margin of trade helps to bring the predicted moments even closer to the empirical ones. The TCM model generates volatilities of imports, exports and trade volume which are even higher than in the TC model and closer to those implied by the data. Regardless of whether business cycles are driven by productivity shocks or demand shocks, the model is able to replicate procyclical trade openness, in line with empirical observation. It also generates higher volatilities of openness than the TC model, which are closer to those observed.

In all versions of the model, net exports are acyclical when business cycles are driven by productivity shocks and countercyclical when cyclical fluctuations are caused by demand shocks, which point to the importance of demand shocks in determining business cycle fluctuations, in line with the results obtained by Jiang (2016).

The analysis demonstrates that an open-economy model incorporating inter-firm lending but excluding many of the features which have traditionally been used to replicate stylized international business cycle facts performs well in explaining key properties of international trade fluctuations. This suggests that trade credit plays an 
important role in determining the dynamics of interational trade over the business cycle and the international transmission of shocks.

\section{Conclusion}

This study analyzes the impact of trade credit on the transmission of shocks in an open economy and, in particular, on the dynamics of international trade. Using British and Irish firm-level data, it shows that an overwhelming majority of firms makes an extensive use of this type of financing. It also demonstrates that firms engaged in international trade use trade credit more actively and more intensively than firms serving only the domestic market. The percentage of firms supplying and receiving trade credit is higher among exporters than non-exporters. Firms exporting their goods also have a significantly higher ratio of trade debtors to sales revenues. The pattern of a more extensive trade credit use by firms participating in international trade prevails not only in the manufacturing sector, which is responsible for a major share of international trade, but also in the entire population of firms in the economy. It is observed among both large and small firms. Given the importance of inter-firm lending in day to day business operations, the objective of this study is to examine whether and to what extent trade credit contributes to the high volatility of imports and exports observed in the data and the high sensitivity of international trade to macroeconomic shocks, which is difficult to reconcile with standard international business cycle models.

The study introduces inter-firm lending into an open economy general equilibrium model with heterogeneous firms in which the decision to enter the exports market is endogenous. The analysis shows that trade credit amplifies the impact of supply and demand shocks on trade both along the intensive and extensive margin. This is the case both for symmetric and country-specific shocks. Trade credit influences the transmission of shocks through the marginal cost channel. Due to the fact that international transactions are associated with greater counterparty risk than domestic transactions, the foreign market price of traded varieties is more sensitive to changes in macroeconomic conditions than their domestic market price, which leads to changes in the relative demand for domestic and foreign goods over the business cycle. The study demonstrates that trade credit has considerable impact on the propagation of shocks in an open economy. It shows that a simple open-economy model accounting for interfirm lending can help explain a number of features of international trade fluctuations, including high volatility of imports and exports and procyclical trade openness. It would be interesting to incorporate inter-firm lending into a richer general equilibrium framework accounting for alternative sources of finance for firms in order to capture the interaction of trade credit with other forms of financing and explore further the role of financial factors in the determination of international business cycles. Furthermore, introducing nominal rigidities into an open economy model with inter-firm lending in order to examine the role of trade credit in the international transmission of monetary shocks constitutes another interesting avenue for future research. 


\section{Appendix}

\section{A.1 Flexible price equilibrium}

This section lists the Home economy equilibrium conditions of the model.

Risk-sharing condition:

$$
\left(\frac{C_{t}}{C_{t}^{*}}\right)^{\sigma} e^{\left(u_{t}^{*}-u_{t}\right)}=\frac{S_{t} P_{t}^{*}}{P_{t}}
$$

Intratemporal labor equation:

$$
\frac{W_{t}}{P_{t}}=C_{t}^{\sigma} L_{t}^{\varphi} e^{-u_{t}}
$$

Intermediate goods aggregator:

$$
X_{t}=\left[\left(\frac{1}{2-N^{*}}\right)^{\frac{1}{\theta_{A}}} X_{H, t}^{\frac{\theta_{A}-1}{\theta_{A}}}+\left(\frac{1-N^{*}}{2-N^{*}}\right)^{\frac{1}{\theta_{A}}} X_{F, t}^{\frac{\theta_{A}-1}{\theta_{A}}}\right]^{\frac{\theta_{A}}{\theta_{A}-1}}
$$

Aggregate intermediate good-domestic producers:

$$
X_{H, t}=\left(\frac{1}{2-N^{*}}\right)\left(\frac{Q_{H, t}}{Q_{t}}\right)^{-\theta_{A}} X_{t}
$$

Aggregate intermediate good-foreign producers:

$$
X_{F, t}=\left(\frac{1-N^{*}}{2-N^{*}}\right)\left(\frac{Q_{F, t}}{Q_{t}}\right)^{-\theta_{A}} X_{t}
$$

Price index for intermediate goods produced and sold in the Home economy:

$$
Q_{H, t}=\frac{\theta_{A}}{\theta_{A}-1} \frac{W_{t}}{Z_{t} A_{A}} g_{H, t}
$$

Price index for intermediate goods produced in the Home economy and sold in the Foreign economy:

$$
Q_{F, t}^{*}=(1+\tau) \frac{\theta_{A}}{\theta_{A}-1} \frac{W_{t}}{Z_{t} A_{E, t}} g_{F, t}^{*} \frac{1}{S_{t}}
$$

Trade credit insurance cost for Home intermediate goods producers for the trade credit granted to Home final goods producers:

$$
g_{H, t}=\frac{1}{\left(1-d_{H}\right)+d_{H}\left(1-\rho_{t}\right)}
$$


Trade credit insurance cost for Home intermediate goods producers for trade credit granted to Foreign final goods producers:

$$
g_{F, t}^{*}=\frac{1}{\left(1-d_{F}\right)+d_{F}\left(1-\rho_{t}^{*}\right)}
$$

Production function-domestic intermediate goods producers:

$$
V_{H, t}=Z_{t} A_{A} L_{H, t}
$$

Production function-foreign intermediate goods producers:

$$
V_{F, t}=Z_{t} A_{E, t} L_{F, t}
$$

Threshold level of productivity—exports market participation condition:

$$
\frac{1}{\theta_{A}}\left(\frac{1}{2-N_{t}}\right)\left((1+\tau) \frac{\theta_{A}}{\theta_{A}-1} \frac{g_{F, t}^{*}}{\bar{A}_{t}}\right)^{1-\theta_{A}}\left(\frac{W_{t}}{Z_{t}}\right)^{-\theta_{A}} X_{t}^{*}\left(S_{t} Q_{t}^{*}\right)^{\theta_{A}}=F_{A}
$$

Probability of exporting:

$$
N_{t}=1-\left(\frac{A_{\min }}{\bar{A}_{t}}\right)^{k_{A}}
$$

The average level of productivity among domestic intermediate goods producers:

$$
A_{A}=\left[\frac{k_{A}}{k_{A}-\left(\theta_{A}-1\right)}\right]^{\frac{1}{\theta_{A}-1}} A_{\min }
$$

The average level of productivity among exporting intermediate goods producers:

$$
A_{E, t}=\left[\frac{k_{A}}{k_{A}-\left(\theta_{A}-1\right)}\right]^{\frac{1}{\theta_{A}-1}} \bar{A}_{t}
$$

The average level of productivity among non-exporting intermediate goods producers:

$$
A_{N, t}=\left[\frac{k_{A}}{k_{A}-\left(\theta_{A}-1\right)}\right]^{\frac{1}{\theta_{A}-1}}\left[\frac{1}{N_{t}} A_{\min }^{\theta_{A}-1}-\frac{\left(1-N_{t}\right)}{N_{t}}\left(\bar{A}_{t}\right)^{\theta_{A}-1}\right]^{\frac{1}{\theta_{A}-1}}
$$

Production function in the sector of final goods producers:

$$
Y_{t}=B_{A} X_{t}
$$

The threshold level of productivity above which firms are able to pay all their financial obligations including trade credit: 


$$
\frac{1}{\theta_{B}-1} \bar{B}_{t}^{\theta_{B}-1} C_{t} Q_{t} B_{A}^{-\theta_{B}}=F_{B} \frac{W_{t}}{Z_{t}}
$$

The threshold level of productivity above which firms are able to pay all their financial obligations apart from trade credit:

$$
\begin{aligned}
F_{B} \frac{W_{t}}{Z_{t}}= & \bar{B}_{j, t}^{\theta_{B}-1} C_{t} B_{A}^{-\theta_{B}} Q_{t}^{\theta_{A}} \frac{\theta_{B}}{\theta_{B}-1} Q_{t}^{1-\theta_{A}} \\
& -\overline{\bar{B}}_{j, t}^{\theta_{B}-1} \quad C_{t} B_{A}^{-\theta_{B}} Q_{t}^{\theta_{A}} \\
& {\left[\left(1-d_{F}\right)\left(\frac{1-N^{*}}{2-N^{*}}\right) Q_{F, t}^{1-\theta_{A}}+\left(1-d_{H}\right)\left(\frac{1}{2-N^{*}}\right) Q_{H, t}^{1-\theta_{A}}\right] }
\end{aligned}
$$

The probability that a firm will default on the entire value of trade credit received:

$$
M_{L, t}=F\left(\overline{\bar{B}}_{t}\right)=1-\left(\frac{B_{\min }}{\overline{\bar{B}}_{t}}\right)^{k_{B}}
$$

The probability that a firm will default on at least a fraction of trade credit received:

$$
M_{H, t}=F\left(\bar{B}_{t}\right)=1-\left(\frac{B_{\min }}{\bar{B}_{t}}\right)^{k_{B}}
$$

The average level of productivity among all final goods producers:

$$
B_{A}=\left[\frac{k_{B}}{k_{B}-\left(\theta_{B}-1\right)}\right]^{\frac{1}{\theta_{B}-1}} B_{\min }
$$

The average level of productivity among non-defaulting final goods producers who are able to pay all their financial obligations:

$$
B_{H H, t}=\left[\frac{k_{B}}{k_{B}-\left(\theta_{B}-1\right)}\right]^{\frac{1}{\theta_{B}-1}} \bar{B}_{t}
$$

The average level of productivity among final goods producers who default on at least a fraction of trade credit received:

$$
B_{H L, t}=\left[\frac{k_{B}}{k_{B}-\left(\theta_{B}-1\right)}\right]^{\frac{1}{\theta_{B}-1}}\left[\frac{1}{M_{H, t}} B_{\min }^{\theta_{B}-1}-\frac{\left(1-M_{H, t}\right)}{M_{H, t}}\left(\bar{B}_{t}\right)^{\theta_{B}-1}\right]^{\frac{1}{\theta_{B}-1}}
$$

The average level of productivity among non-defaulting final goods producers who are able to pay all their financial obligations apart from the trade credit: 


$$
B_{L H, t}=\left[\frac{k_{B}}{k_{B}-\left(\theta_{B}-1\right)}\right]^{\frac{1}{\theta_{B}-1}} \overline{\bar{B}}_{t}
$$

The average level of productivity among final goods producers who default on the entire value of trade credit received:

$$
B_{L L, t}=\left[\frac{k_{B}}{k_{B}-\left(\theta_{B}-1\right)}\right]^{\frac{1}{\theta_{B}-1}}\left[\frac{1}{M_{L, t}} B_{\min }^{\theta_{B}-1}-\frac{\left(1-M_{L, t}\right)}{M_{L, t}}\left(\overline{\bar{B}}_{t}\right)^{\theta_{B}-1}\right]^{\frac{1}{\theta_{B}-1}}
$$

Trade credit default rate among final goodsproducers:

$$
\begin{aligned}
& \rho_{t}= \frac{M_{H, t} B_{H L, t}^{\theta_{B}-1}+\left(\bar{B}_{t}-\overline{\bar{B}}_{t}\right) F_{B} \frac{W_{t}}{Z_{t}} \frac{1}{Q_{t} C_{t}} B_{A}^{\theta_{B}}}{\left[d_{H}\left(\frac{1}{2-N^{*}}\right) Q_{H, t}^{1-\theta_{A}}+d_{F}\left(\frac{1-N^{*}}{2-N^{*}}\right) Q_{F, t}^{1-\theta_{A}}\right] B_{A}^{\theta_{B}-1} Q_{t}^{\theta_{A}-1}} \\
&-\frac{\left[\left(1-d_{H}\right)\left(\frac{1}{2-N^{*}}\right) Q_{H, t}^{1-\theta_{A}}+\left(1-d_{F}\right)\left(\frac{1-N^{*}}{2-N^{*}}\right) Q_{F, t}^{1-\theta_{A}}\right] Q_{t}^{\theta_{A}-1} M_{L, t} B_{L L, t}^{\theta_{B}-1}}{\left[d_{H}\left(\frac{1}{2-N^{*}}\right) Q_{H, t}^{1-\theta_{A}}+d_{F}\left(\frac{1-N^{*}}{2-N^{*}}\right) Q_{F, t}^{1-\theta_{A}}\right] B_{A}^{\theta_{B}-1} Q_{t}^{\theta_{A}-1}} \\
&-\frac{\theta_{B}}{\theta_{B}-1}\left(M_{H, t} B_{H L, t}^{\theta_{B}-1}-M_{L, t} B_{L L, t}^{\theta_{B}-1}\right) \\
& {\left[d_{H}\left(\frac{1}{2-N^{*}}\right) Q_{H, t}^{1-\theta_{A}}+d_{F}\left(\frac{1-N^{*}}{2-N^{*}}\right) Q_{F, t}^{1-\theta_{A}}\right] B_{A}^{\theta_{B}-1} Q_{t}^{\theta_{A}-1} }
\end{aligned}
$$

Labour market equilibrium condition:

$$
L_{t}=L_{H, t}+L_{F, t}+\frac{1}{Z_{t}}\left[F_{B}+\left(1-N_{t}\right) F_{A}\right]
$$

Resource constraint in the market for final consumption goods:

$$
Y_{t}=C_{t}
$$

Resource constraint in the market for intermediate goods:

$$
\begin{aligned}
& V_{H, t}=X_{H, t} \\
& V_{F, t}=X_{F, t}^{*}
\end{aligned}
$$

Normalization:

$$
\begin{aligned}
& P_{t}=1 \\
& S_{t}=1
\end{aligned}
$$

The complete model consists of all the above listed equilibrium conditions for the Home economy and the Foreign-economy equivalents of these conditions. 


\section{A.2 Structural parameters}

See Table 4.

Table 4 Structural parameters

\begin{tabular}{|c|c|c|c|c|}
\hline \multirow[t]{2}{*}{ Parameter } & \multirow[t]{2}{*}{ Description } & \multicolumn{3}{|l|}{ Value } \\
\hline & & TCM & $\mathrm{TC}$ & BS \\
\hline$\sigma$ & $\begin{array}{l}\text { Inverse of the intertemporal elasticity of substitution in con- } \\
\text { sumption }\end{array}$ & 2.0 & 2.0 & 2.0 \\
\hline$\varphi$ & Inverse of the Frisch elasticity of labor supply & 2.0 & 2.0 & 2.0 \\
\hline$\beta$ & Discount factor & 0.99 & 0.99 & 0.99 \\
\hline$\theta_{A}$ & Elasticity of substitution-intermediate goods & 6.0 & 6.0 & 6.0 \\
\hline$\theta_{B}$ & Elasticity of substitution-final consumption goods & 6.0 & 6.0 & 6.0 \\
\hline$\tau$ & Iceberg trade costs & 0.2 & 0.2 & 0.2 \\
\hline$k_{A}$ & $\begin{array}{l}\text { Pareto distribution shape parameter-intermediate goods } \\
\text { producers }\end{array}$ & 6.25 & 6.25 & 6.25 \\
\hline$k_{B}$ & $\begin{array}{l}\text { Pareto distribution shape parameter-final consumption goods } \\
\text { producers }\end{array}$ & 6.25 & 6.25 & 6.25 \\
\hline$F_{A}$ & Fixed cost of exporting & 0.1489 & - & - \\
\hline$F_{B}$ & Fixed cost of production-sector of final consumption goods & 0.0235 & 0.0235 & 0.0235 \\
\hline$d_{H}$ & $\begin{array}{l}\text { Fraction of sales for which trade credit is granted to domestic } \\
\text { buyers }\end{array}$ & 0.55 & 0.0 & 0.0 \\
\hline$d_{F}$ & $\begin{array}{l}\text { Fraction of sales for which trade credit is granted to foreign } \\
\text { buyers }\end{array}$ & 0.75 & 0.0 & 0.0 \\
\hline$\rho^{a}$ & Trade credit default rate & - & - & 0.0 \\
\hline$N^{b}$ & Share of non-exporters among intermediate goods producers & - & 0.65 & 0.65 \\
\hline$\gamma_{z}, \psi_{z}$ & $\begin{array}{l}\text { Persistence of productivity shocks in the intermediate goods } \\
\text { sector }\end{array}$ & 0.906 & 0.906 & 0.906 \\
\hline$\psi_{z z^{*}}$ & $\begin{array}{l}\text { Persistence of productivity shocks in the intermediate goods } \\
\text { sector }\end{array}$ & 0.088 & 0.088 & 0.088 \\
\hline$\gamma_{u}, \psi_{u}$ & Persistence of demand shocks & 0.896 & 0.896 & 0.896 \\
\hline$\psi_{u u^{*}}$ & Persistence of demand shocks & 0.1038 & 0.1038 & 0.1038 \\
\hline$\phi_{z}$ & Standard deviation of productivity innovations & 0.00852 & 0.00852 & 0.00852 \\
\hline$\phi_{u}$ & Standard deviation of demand innovations & 0.015 & 0.015 & 0.015 \\
\hline$\kappa_{\zeta_{t}^{z}, \xi_{t}^{z^{*}}}$ & Correlation of productivity innovations & 0.288 & 0.288 & 0.288 \\
\hline$\kappa_{\zeta_{t}^{u}, \zeta_{t}^{u^{*}}}$ & Correlation of demand innovations & 0.3647 & 0.3647 & 0.3647 \\
\hline
\end{tabular}

$T C M$ trade credit model with extensive margin, $T C$ trade credit model, $B S$ baseline model

${ }^{a}$ The parameter $\rho$ is an endogenous variable in the TC and TCM models

${ }^{b}$ The parameter $N$ is an endogenous variable in the TCM model 
Funding Financial support from the Economic and Social Research Council, UK, and Corpus Christi College, Cambridge, UK, is gratefully acknowledged.

Data availability The data that support the findings of this study are available from the OECD Economic Outlook database and from the Bureau van Dijk's Fame database upon subscription.

Code availability The codes that support the findings of this study are available from the author on request.

\section{Declarations}

Conflict of interest The author states that there is no conflict of interest.

Open Access This article is licensed under a Creative Commons Attribution 4.0 International License, which permits use, sharing, adaptation, distribution and reproduction in any medium or format, as long as you give appropriate credit to the original author(s) and the source, provide a link to the Creative Commons licence, and indicate if changes were made. The images or other third party material in this article are included in the article's Creative Commons licence, unless indicated otherwise in a credit line to the material. If material is not included in the article's Creative Commons licence and your intended use is not permitted by statutory regulation or exceeds the permitted use, you will need to obtain permission directly from the copyright holder. To view a copy of this licence, visit http://creativecommons.org/licen ses/by/4.0/.

\section{References}

Ahn, J. (2011). A theory of domestic and international trade finance, IMF Working Paper No. 11/262.

Aiello, F., Bonanno, G., \& Via, A. (2015). Again on trade elasticities: Evidence from a selected sample of countries. Eurasian Business Review, 5, 259-287.

Alessandria, G., Kaboski, J., \& Midrigan, V. (2010). The Great Trade Collapse of 2008-09: An inventory adjustment? IMF Economic Review, 58(2), 254-294.

Alexandre, M., \& Lima, G. (2020). Macroeconomic impacts of trade credit: An agent-based modeling exploration. EconomiA, 21(2), 130-144.

Anderson, J., \& van Wincoop, E. (2004). Trade costs. Journal of Economic Literature, 42(3), 691-751.

Antràs, P., \& Foley, C. F. (2015). Poultry in motion: A study of international trade finance practices. Journal of Political Economy, 123(4), 853-901.

Asmundson, I., Dorsey, T., Khachatryan, A., Niculcea, I., \& Saito, M. (2011). Trade and trade finance in the 2008-09 financial crisis, IMF Working Paper No. WP/11/16.

Atanasova, C., \& Wilson, N. (2003). Bank borrowing constraints and the demand for trade credit: Evidence from panel data. Managerial and Decision Economics, 24(6-7), 503-514.

Auboin, M. (2009). Restoring trade finance during a period of financial crisis: Stock-taking of recent initiatives, WTO Staff Working Paper No. ERSD-2009-16.

Axtell, R. (2001). Zipf distribution of U.S. firm sizes. Science, 293(5536), 1818-1820.

Backus, D., Kehoe, P., \& Kydland, F. (1992). International real business cycles. Journal of Political Economy, 100, 745-775.

Bellone, F., Musso, P., Nesta, L., \& Schiavo, S. (2010). Financial constraints and firm export behaviour. The World Economy, 33(3), 347-373.

Bems, R., Johnson, R., \& Yi, K. (2010). The role of vertical linkages in the propagation of the global downturn of 2008. IMF Economic Review, 58(2), 295-326.

Bernard, A., \& Jensen, J. (1995). Exporters, jobs and wages in U.S. manufacturing, 1976-1987. Brookings Papers on Economic Activity, Microeconomics, 1995, 67-119.

Bernard, A., \& Jensen, J. (1997). Exporters skill-upgrading and the wage gap. Journal of International Economics, 42(1), 3-31. 
Bernard, A., \& Jensen, J. (1999). Exceptional exporter performance: Cause, effect or both? Journal of International Economics, 47(1), 1-25.

Bernard, A., \& Jensen, J. (2004). Why some firms export. Review of Economics and Statistics, 86(2), 561-569.

Boileau, M. (1999). Trade in capital goods and the volatility of net exports and the terms of trade. Journal of International Economics, 48, 347-365.

Boissay, F. (2006). Credit chains and the propagation of financial distress, ECB Working Paper No. 573.

Boissay, F., \& Gropp, R. (2007). Trade credit defaults and liquidity provision by firms, ECB Working Paper No. 753.

Bradley, D., \& Cowdery, C. (2004). Small business: Causes of bankruptcy, Technical Report, University of Central Arkansas.

Bradley, D., \& Rubach, M. (2002). Trade credit and small business: A cause of business failure?, Technical Report, University of Central Arkansas.

Buch, C., Kesternich, I., Lipponer, A., \& Schnitzer, M. (2010). Exports vs. FDI revisited: Does finance matter?, CEPR Discussion Paper No. 7839.

Bussière, M., Callegari, G., Ghironi, F., Sestieri, G., \& Yamano, N. (2013). Estimating trade elasticities: Demand composition and the trade collapse of 2008-09. American Economic Journal: Macroeconomics, 5(3), 118-151.

Calomiris, C., Himmelberg, C., \& Wachtel, P. (1995). Commercial paper, corporate finance, and the business cycle: A microeconomic perspective. Carnegie-Rochester Conference Series on Public Policy, 42, 203-250.

Cardoso-Lecourtois, M. (2004). Chain reactions, trade credit and the business cycle, Econometric Society 2004 North American Summer Meetings, No. 331.

Chaney, T. (2016). Liquidity constrained exporters. Journal of Economic Dynamics and Control, 72(C), $141-154$.

Choi, W., \& Kim, Y. (2005). Trade credit and the effect of macro-financial shocks: Evidence from U.S. panel data. Journal of Financial and Quantitative Analysis, 40(4), 897-925.

Corsetti, G., Dedola, L., \& Leduc, S. (2008). International risk sharing and the transmission of productivity shocks. Review of Economic Studies, 75(2), 443-473.

Corsetti, G., Martin, P., \& Pesenti, P. (2007). Productivity, terms of trade and the home market effect. Journal of International Economics, 73(1), 99-127.

Cuñat, V. (2007). Trade credit: Suppliers as debt collectors and insurance providers. Review of Financial Studies, 20(2), 491-527.

Dass, N., Kale, J., \& Nanda, V. (2015). Trade credit, relationship-specific investment, and product-market power. Review of Finance, 19(5), 1867-1923.

Demirguc-Kunt, A., \& Maksimovic, V. (2001). Firms as financial intermediaries-evidence from trade credit data, World Bank Policy Research Working Paper No. 2696.

Djankov, S., Freund, C., \& Pham, C. (2010). Trading on time. Review of Economics and Statistics, 92(1), 166-173.

Eaton, J., Kortum, S., Neimann, B., \& Romalis, J. (2016). Trade and the global recession. American Economic Review, 106(11), 3401-3438.

Eck, K., Engemann, M., \& Schnitzer, M. (2012). How trade credits foster international trade, CEPR Discussion Papers No. 8954.

Engel, C., \& Wang, J. (2011). International trade in durable goods: Understanding volatility, cyclicality and elasticities. Journal of International Economics, 83(1), 37-52.

Erceg, C.J., Guerrieri, L., Gust, C. (2008). Trade adjustment and the composition of trade. Journal of Economic Dynamics and Control, 32(8), 2622-2650. https://doi.org/10.1016/j.jedc.2007.09.015

Faia, E. (2007). Finance and international business cycles. Journal of Monetary Economics, 54, 1018-1034.

Freund, C. (2009). The trade response to global downturns: Historical evidence, World Bank Policy Research Working Paper No. 5015.

Garcia-Appendini, E., \& Montoriol-Garriga, J. (2013). Firms as liquidity providers: Evidence from the 2007-2008 financial crisis. Journal of Financial Economics, 109(1), 272-291.

Ghironi, F., \& Melitz, M. (2005). International trade and macroeconomic dynamics with heterogeneous firms. Quarterly Journal of Economics, 120(3), 865-915.

Guariglia, A., \& Mateut, S. (2006). Credit channel, trade credit channel, and inventory investment: Evidence from a panel of UK Firms. Journal of Banking and Finance, 30(10), 2835-2856. 
Huang, H., Shib, X., \& Zhang, S. (2011). Counter-cyclical substitution between trade credit and bank credit. Journal of Banking and Finance, 35(8), 1859-1878.

Hummels, D. L., \& Schaur, G. (2013). Time as a trade barrier. American Economic Review, 103(7), 2935-2959.

Iacoviello, M., \& Minetti, R. (2006). International business cycles with domestic and foreign lenders. Journal of International Economics, 53, 2267-2282.

Irwin, D. (2002). Long-run trends in world trade and income. World Trade Review, 1(1), 89-100.

Jacobson, T., \& Schedvin, E. (2015). Trade credit and the propagation of corporate failure: An empirical analysis. Econometrica, 83(4), 1315-1371.

Jiang, M. (2016). By force of demand: Explaining cyclical fluctuations of international trade and government spending. Journal of Economic Dynamics and Control, 69, 249-267.

Khan, M. A., Qin, X., \& Jebran, K. (2020). Uncertainty and leverage nexus: Does trade credit matter? Eurasian Business Review, 10, 355-389.

Kiyotaki, N., \& Moore, J. (1997). Credit chains, Edinburgh School of Economics Discussion Paper No. 118.

Klapper, L., Laeven, L., \& Rajan, R. (2012). Trade credit contracts. Review of Financial Studies, 25(3), $838-867$.

Kohler, M., Britton, E., \& Yates, A. (2000). Trade credit and the monetary transmission mechanism, Bank of England Working Paper No. 115.

Kollmann, R., Enders, Z., \& Muller, G. (2011). Global banking and international business cycles. European Economic Review, 55, 407-426.

Krugman, P. (1989). Differences in income and trends in real exchange rates. European Economic Review, 33(5), 1031-1054.

Levchenko, A., Lewis, L., \& Tesar, L. (2010). The collapse of international trade during the 2008-2009 crisis: In search of the smoking gun. IMF Economic Review, 58(2), 214-253.

Love, I., Preve, L., \& Sartia-Allende, V. (2007). Trade credit and bank credit: Evidence from recent financial crises. Journal of Financial Economics, 83(2), 453-469.

Manova, K. (2013). Credit constraints, heterogeneous firms, and international trade. Review of Economic Studies, 80(2), 711-744.

Mateut, S., Bougheas, S., \& Mizen, P. (2006). Trade credit, bank lending and monetary policy transmission. European Economic Review, 50(3), 603-629.

Melitz, M. (2003). The impact of trade on intra-industry reallocations and aggregate industry productivity. Econometrica, 71(6), 1695-1725.

Minetti, R., \& Chun Zhu, S. (2011). Credit constraints and firm export: Microeconomic evidence from Italy. Journal of International Economics, 83(2), 109-125.

Muuls, M. (2015). Exporters, importers and credit constraints. Journal of International Economics, 95(2), 333-343.

Obstfeld, M., \& Rogoff, K. (2001). The six major puzzles in international macroeconomics: Is there a common cause? NBER chapters. NBER Macroeconomics Annual, 2000(15), 339-412.

OECD. (2010). Sensitivity of trade flows to price and income changes, In Measuring globalisation: OECD economic globalisation indicators 2010. OECD Publishing.

Patel, N. (2016). International trade finance and the cost channel of monetary policy in open economies, BIS Working Papers. No 539.

Perri, F., \& Quadrini, V. (2018). International recessions. American Economic Review, 108, 935-984.

Petersen, M., \& Rajan, R. (1997). Trade credit: Theory and evidence. Review of Financial Studies, 10(3), 661-691.

Raddatz, C. (2010). Credit chains and sectoral comovements: Does the use of trade credit amplify sectoral shocks? Review of Economics and Statistics, 92(4), 985-1003.

Raffo, A. (2008). Net exports, consumption volatility and international business cycle models. Journal of International Economics, 75(1), 14-29.

Rajan, R., \& Zingales, L. (1995). What do we know about capital structure? Some evidence from international data. Journal of Finance, 50(5), 1421-1460.

Ravn, M., \& Mazzenga, E. (2004). International business cycles: The quantitative role of transportation costs. Journal of International Money and Finance, 23(4), 645-671.

Redding, S. (2011). Theories of heterogeneous firms and trade. Annual Review of Economics, 3(1), 77-105.

Schmidt-Eisenlohr, T. (2013). Towards a theory of trade finance. Journal of International Economics, 91(1), 96-112. 
Wilson, N., \& Summers, B. (1997). Trade credit terms and the motives for trade credit extension: Theory and evidence, University of Bradford Management Centre Working Paper No. 9708.

Yang, X. (2011). Trade credit versus bank credit: Evidence from corporate inventory financing. The Quarterly Review of Economics and Finance, 51(4), 419-434.

Yao, W. (2019). International business cycles and financial frictions. Journal of International Economics, $118,283-291$.

Publisher's Note Springer Nature remains neutral with regard to jurisdictional claims in published maps and institutional affiliations. 